
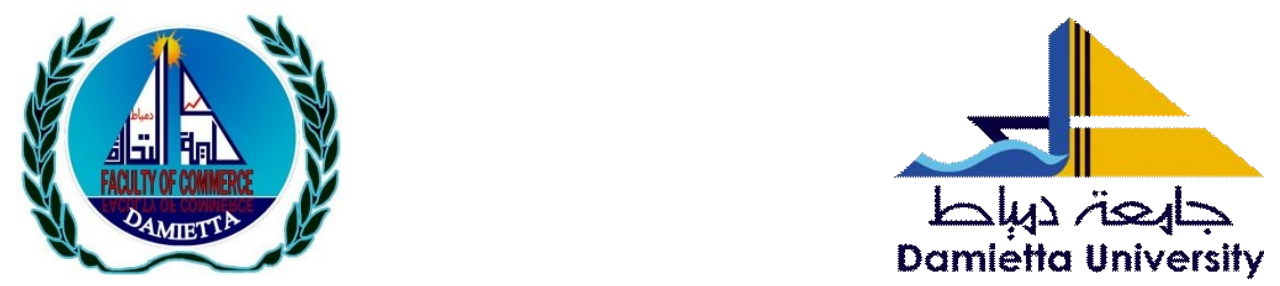

\title{
Corporate Governance, Environmental and Social Responsibility and Firm Performance: Evidence from Egypt
}

$$
\text { By }
$$

Prof. Dr. Mohamed A. EL-Hindawy

Professor of Business Administration

Faculty of Commerce - Damietta

University hendmarkeg@yahoo.com

\section{Dr. Amir Ali Al Morsi Shousha}

Assistant Prof. of Business Administration

Faculty of commerce, Damietta University

\section{Ahmed Mostafa Rady}

PHD. Researcher of Business Administration

Scientific Journal for Financial and Commercial Studies and Researches (SJFCSR)

Faculty of Commerce - Damietta University

Vol.2, No.1, Part 1., Jan. 2021

\section{APA Citation:}

EL-Hindawy, M. A. M.; Shusha, A.; and Rady, A. M. (2021). Corporate Governance, Environmental and Social Responsibility and Firm Performance: Evidence from Egypt, Scientific Journal For Financial and Commercial Studies and Research, Faculty of Commerce, Damietta University, 2(1), pp. 455- 526.

Website: https://cfdj.journals.ekb.eg/ 


\begin{abstract}
This research examines the impact of corporate governance on firm performance, as well as it examines the indirect relationship through mediating environmental social responsibility between the corporate governance and firm performance. Panel data regression was performed on a sample of 66 non -financial firms in Egypt during the period from 2010-2018. The model parameters were estimated using generalized least square regression. Six corporate governance indicators (Ownership concentration, Female directorship, Role Duality, Board independence, Board size and Audit reputation) were chosen in testing the hypothesized relationship between corporate governance practices with firm performance, which was measured by return on asset, return on equity and Tobin's q. Moreover, environmental social responsibility factor is measured using the S\&P/EGX ESG ratings Published index. The results show that environmental social responsibility partially mediates the relationship between audit reputation, role duality and ownership concentration with return on asset. Moreover, the results show that environmental social responsibility fully mediate the relationship between role duality and return on equity. On the other hand, the results show environmental social responsibility doesn't mediate the relationship between corporate governance and Tobin's q.
\end{abstract}

Keywords: Corporate Governance, Environmental Social Responsibility, Firm Performance, Tobin's q and Egypt. 


\section{1- Introduction}

In recent years, there has been an increasing interest in both environmental and social responsibility and in corporate governance mechanism as large separated research areas. However, so far there has been less attention of linking both research areas together. Ali et al. (2017) argued that corporate social responsibility (CSR) is derived by the mechanisms of corporate governance (CG), since CSR activities is greatly influenced by values and motives of those who are involved in formulating and making decisions in the firms, and hence, board characteristics as one of the mechanisms of CG could be a permanent determinant with profound impact in shaping the CSR activities (Haniffa and Cooke, 2005). Moreover, Khan et al, (2013) argued that corporate governance is a precision system of rules and processes by which corporations are managed and controlled. And since corporate environmental and social responsibility is affected and influenced by those who are taking decisions, and formulating the strategic policies in the organizations. The governance mechanisms like ownership structure and board independence could be critical and important determinants in shaping the environmental and social activities in the organizations. (Gibbins et al. 1990; Haniffa and Cooke 2005).

Van der Laan Smith et al., (2005) have defined corporate governance as the relationship between the corporation and its stakeholders. And corporate social responsibility is defined as "a discretionary allocation of corporate resources toward improving welfare that serves as a means of enhancing relationships with key stakeholders", both variables are related and correlated to the framework of the legitimacy theory, and this relation could define the interaction between the firm and its internal and external sociopolitical environment (Windsor and Preston,

Vol.2, No.1, Part 1., Jan. 2021 
1988). Moreover, Van der Laan Smith et al., (2005), in his research has pointed out that the interaction between both corporate governance and corporate social responsibility, is considered as complementary vital prerequisites for integrated growth in the global business environment.

Numerous studies have attempted to explain and define corporate governance (CG) and its implications. Cadbury, (2000) explained corporate governance as the separation of the ownership of the business and the control system in which the organization is directed and managed. Corporate governance is the supervision, management, and control of all the managerial and operational decision that determines and accomplishes the goals of the organization and the achievement of its objectives. Also, $\mathrm{CG}$ is defined as the set of mechanisms that helps to control and manage the organization performance and its strategic directions, and settle the conflicting interest among stakeholders. (c.a. Casillas, and Moreno, 2010).

Focusing on the social content is becoming a key main concern for all organizations to maximize economic performance and satisfaction of the shareholders. Therefore, acting in a social, environmental and economical way, requires from the organizations a fully integrated system which takes into account all the considerations and concerns of social and environmental issue, for the society in general and stakeholder in particular. However, generally, shareholder is acting their role in an ethical manner at the corporate level and thereby requires influencing the board of directors to formulate the organization strategies in the same following social, environmental and economic manners and ethics. (Pava and Krausz, 1996). 
Maximizing profit is no more an acceptable issue for corporations to do business. Profit is not the only motive for doing business however the business must have responsibility toward the society. (c.a. Echave and Bhati, 2010). Consequently, scholars are trying to show that there is a financial motive for organizations to engage in corporate environmental and social responsibility. (McWilliams and Siegel, 2000; Orlitzky et al., 2003; Russo and Fouts, 1997; Waddock and Graves, 1997). Numerous studies have argued that the engagement in CSR adds both tangible (e.g. 'best practices'; Christmann, 2000) and intangible (e.g. reputation; Margolis et al., 2009) assets to a firm; which improve the performance of the organization, and hence, improve its financial position. However, till date there are mixed results between the important of the engagement of the environmental social responsibility and firm performance.

Several studies have defined social responsibility; however, for the purpose of this study the following definition for (Williams 1999, p.62) will be used. Williams (1999) define corporate social responsibility (CSR) as "the information that is voluntarily communicated by the organizations about their activities, programs and applications of their resources which affect their relevant public image to meet social, political and economic demands the definition given by Williams (1999) articulates the willingness of the corporations to go beyond their legal obligations in pursuing their environmental social responsibility (ESR). The emphasis is on voluntary disclosures of relevant information about the firm's activity on society. These disclosures should include details about physical, environmental, energy, human resources, products and community involvement issues. 
The following studies underlie a set of different theories that support the relationship between the proposed variables. Agency theory by (Jensen and Meckling, 1976; Fama, 1980; Fama and Jensen, 1983) has argued that there is a main conflict or a discountenance interest between the principal "shareholders" and the agent "manager". Mangers may not perfectly act in the shareholders' interests, which interfere the flexible running of the organization. This might cause miscommunication between the agent and the principle and lead to inefficiency and financial losses. The agent problem can be minimized by strict corporate policy. Corporate governance can be used to change the rules under which the agent operates and restore the principal's interests (Cadbury, 2000). Due to the, power and control of corporate governance on the asset and management of the firm, corporate governance prescribe a number of mechanisms which will help to find solutions for agency theories, such as large share holdings, independent boards of directors, alternative executive compensation, and the takeover market.

The principal-agent model of corporate governance has been challenged by many other perspectives, among which stewardship theory has gained much popularity. In the principal agent model, the "model of man" is "that of self-interested actor rationally maximizing their own personal economic gain"; in the stewardship model, however, the model of man is "that of a steward who is motivated by a need to achieve, to gain intrinsic satisfaction through successfully performing inherently challenging work, to exercise responsibility and authority, and thereby to gain recognition from peers and bosses" (Donaldson and Davis, 1991, p. 51). 
Stewardship Theory has an alternative point of view, which emphasize on the existence of ethical and professional motives between the Manger and the shareholders that will overcome the conflict resulting from both side (Muth and Donaldson, 1998). The stewardship theory propose that the managers are honest people (Donaldson and Preston, 1995), and are good resources managers and accomplish good business tracks (Davis et al., 1997) and elaborate for the shareholders' interests (Donaldson and Davis, 1991). Therefore, the decision taking by the board will results in maximizing firm performance and implementation of social environmental responsibility policies (Ingley et al., 2011). Stewardship theory suggests that $\mathrm{CG}$ empower management rather than control them, it assumes that the interest of shareholder's is aligned with executives' behaviors (Donaldson and Davis, 1991, p. 51).

As a theme identified in these responses, "A growing number of regulators globally are reviewing the governance arrangements of corporations to ensure that corporate practices are aligned with broader societal interests"' (Ioannou and Serafeim 2015).

A large and growing body of literature has investigated and examined withier the relationship between CG and FP is direct or indirect (for example, Duffhues and Kabir, 2008; Bhagat and Bolton, 2008; Yang and Zhao, 2014) have found a direct relationship between the CG and FP however, others have found an indirect effect between CG and FP. Mcdonald et al. (2008) had found that CEOs' external advice network mediates the effect of CEO stock ownership on FP in united states firms. Moreover, Zhang et al. (2014) had found that research and development investment mediate the relationship between ownership concentration and FP examining a sample of Chinese Information Technology firms.

Vol.2, No.1, Part 1., Jan. 2021 
Accordingly, the research gap is represented in the need to identify whether the ESR explains the relationship between CG and FP especially for firms listed on the Egyptian Exchange - one of the leading stock exchanges in Middle East and North Africa (MENA) region. Hence, the statement of research problem is: environmental and social responsibility (ESR) a potential mediator between corporate governance and firm performance?

To our best knowledge, this question has not been undertaken in the recent literature. A large and growing body of literature has investigated and focused on (1) the effect of CG on FP. (for example, Chen et al., 2005; Hossain et al., 2001; Pillai and Al-Malkawi,2018; Danoshana et al.,2019; Hussain et al., 2019) (2) The effect of CG on ESR (for example, Johnson and Greening 1999; Jo and Harjoto 2011). (3) The effect of ESR on FP. (McGuire et al., 1988; Waddock and Graves, 1997; McWilliams and Siegel, 2000; Orlitzky et al., 2003; Smith, 2003; Ortas et al., 2014; Liao et al., 2018)

Moreover, since most of the empirical research was limited to the developed and emerging economy setting, we strongly believe that this paper provides a novel contribution to the existing literature as the researcher examines the impact of (CG) mechanism on (FP) and (ESR) and also the effect of (ESR) on (FP), In the MENA region specifically in Egypt. Moreover, investigating the mediating effect of ESR on the relationship between CG on FP is to the best of our knowledge So far, has been no discussion in the Egyptian market which is considered one of the leading stock exchanges in the MENA region, due to its number of listed companies (228), total value traded (265 billion EGP), total volume traded (66 billion securities), and market capitalization (601 billion EGP) which represents 25\% of GDP (The Egyptian Exchange, the annual report 2016, pp.29-30).

Vol.2, No.1, Part 1., Jan. 2021 
In conclusion we can underlie the objective of this study as, first, attempts to examine the impact of CG on FP, and on ESR, also undertake the effect of ESR, on FP second, the study will examine whether the ESR mediate the relationship between CG and FP. On the Egyptian Exchange listed non-financial firms as one of the leading stock exchanges in Middle East and North Africa region.

The rest of our paper is organized as follows. In Section 2, the researcher reviews the relevant literature and develops the research hypotheses. Section 3, highlights the research objectives of the study, Section 4, describes research methodology. Section 5, describes the statistical models and the empirical results and discussions. Section 6 identifies research conclusion and managerial implications. Section 7, limitations and recommendation for future researches 8 , is the acknowledgements for the author.

\section{Research objectives}

The research aims to achieve these objectives

2.1. Examine the impact of corporate governance on firm performance

2.2. Examine the impact of corporate governance on environmental and social responsibility

2.3. Examine the impact of environmental and social responsibility on firm performance

2.4 Test whether environmental and social responsibility mediates the relationship between corporate governance and firm performance.

Vol.2, No.1, Part 1., Jan. 2021 


\section{3- Literature review}

This section aims to review the literature controversy regarding the impact of CG on FP, and on ESR, also undertake the effect of ESR, on FP.

\subsection{Corporate governance and firm performance}

Karpoff, (2001) argued that, there are two categories of corporate governance mechanisms which are the internal mechanism (e.g. board size, board independence and board of directors) and the external mechanism (e.g. competitive market conditions, the market for managerial labor and talent and market for corporate control). This research will spot the light on six factors of the internal mechanism of the corporate governance, which are Board size, Female directorship, Ownership concentration, Audit reputation, board independence, and Role Duality. These factors are explained in the following subsections.

\subsubsection{The effect of board size on firm performance}

Board size is defined as the total executive and non- executive number of directors in the board (Panasian et al., 2003; Levrau and Vanden Berghe, 2007). There is no an optimal number of boards for governing the firm, it varies from one country to another according to its culture. For example, firms in United Kingdom, Holland and Switzerland tend to have small board size while France, Spain and German tend to have large board size from thirteen to eighteen. (Heidrick and Struggles,2007). 
Anderson, (2004) argued that the director ability and control managers is affected and influenced by the size of the board of directors, which mean that the greater the board of director the better access and authority to the resources then the small board. Also, the more experience and knowledge the board of director have the more accurate and effective decisions they take, which will result to high and better performance at the organization.

A large and growing body of literature has investigated the effect of board size on firm performance due to its important mechanism in corporate governance; however, there are no consensus findings on the relationship between both variables. According to previous studies, some researched like (Shukeri et al., 2012; Adam and Mehran, 2003; Kiel and Nicholson, 2003), Have found appositive effect between firm performance and corporate governance. Also, chen et al. (2005) have found a positive relation between board size and earning per share EPS. Other like shukeri et al (2012) argued that there is a positive effect between board size and firms return on asset ROA.

On the other hand, researchers like (Mishra et al., 2001; Singh and Davidson, 2003) found a negative effect between board size and firm performance. Also (Eisenberg et al. 1998) in their study of small and medium sample Finnish firms have found a negative correlation between board size and profitability, in the one hand, Mishra et al., (2001) have found a consistent result with the study of corporate governance of family firms in Norway. Similarly, Yermack (1996) highlighted a negative relationship between the two variables in his study of the U.S. industrial cooperation over a time period of 1984 to 1991 for a sample of 452 industrial firms. Also, Mak and Kusnadi (2005), in his study of Malaysia and Singapore firm has found a negative effect between board size and firm value measured by Tobin's Q. Therefore, we propose the following hypothesis.

Hypothesis 1.1Board size has a significant effect on firm performance.

Vol.2, No.1, Part 1., Jan. 2021 


\subsubsection{The effect of board independence on firm performance}

Board independence also known as (outside director) is measured as the total number of independent non-executive director to the total number of board director (Prabowo and Simpson, 2011). Abdullah and Nasir (2004) also defined board independence as the level of independent director to the director of the board. The role of the independent director is very important in monitoring the firm management team, which in the same time will attract the investors. (Muniandy and Hillier, 2015).

A number of studies have examined the board independence and firm performance, but to date there is no consensus effect between both variables. Dehaene et al. (2001) in their research of Belgian companies argued that there is a positive correlation between board independence and ROE; Also, Byrd et al. (2009) unveiled the positively significant effect of independent director and firm performance. On the one hand, Jackling and Johl (2009) in their research of India's firms have found a positive impact between independent director and firm performance. However, Haniffa and Hudaib (2006) unveiled that there is no effect between board independence and firm performance. Similarly, Chen et al. (2005) found that the number of independent directors in the board has small effect on firm performance. Though, the following hypothesis is proposed.

Hypothesis 1.2 Board independence has a significant effect on firm performance. 


\subsubsection{The effect of female directorship on firm performance}

Female directorship is defined as the percentage of women at the board of directors (Erhardt et al., 2003). Historically the board of director is mainly comprised of male directors, however, this phenomenon is changing due the importance of the existence of female directors in the board. Diversity of the directors will lead to more creative and innovative thinking it also will provide different points of views which will enhance firm performance (Detthamrong et al., 2017). Erhardt et al. (2003) investigated the relationship between demographic board on diversity and firm performance, and the results showed a positive and significant relation. Also, García-Meca et al. (2015) have found that board diversity improves firm performance in their study of the sample of banks in nine counties (Canada, France, Germany, Italy, the Netherlands, Spain, Sweden, the UK, and the US). However, Rose (2007) in his study in listed firms Denmark has found no significance between female directors and firm performance. Consistent with the literature, we propose the flowing hypothesis.

Hypothesis 1.3 Female directorship has a significant effect on firm performance.

\subsubsection{The effect of role duality on firm performance}

Role duality is the one person as the chief executive officer (CEO) is also the chairperson of the board of directors. Detthamrong et al. (2017) argue that CEO duality will lead to a poorer effect of firm performance then firms with non-CEO duality, however, duality of CEO might improve decision making process it also could speed the decision making process but this could be an advantage in fast changing environment, and a

Vol.2, No.1, Part 1., Jan. 2021 
disadvantage in unconsents and inappropriate fast decision. In the one hand, being the CEO and the chairman of the board was a reason of firm failure in Enron and WorldCom. A number of studies have examined the effect of CEO duality and firm performance resulting in negative association between both variables, for example Chen et al. (2005) who examine firms in Hong Kong from period 1995-1998 also, Haniffa and Hudaib (2006) find a negative effect between CEO duality and firm performance in Malaysia. Therefore, we propose the following hypothesis Hypothesis 1.4 Role duality has a significant effect on firm performance.

\subsubsection{The effect of ownership concentration on firm performance}

Different authors have studied the effect of ownerships concentration and firm performance; however, there is no sureness on the effect on both variables. Maury, (2006) argue that the managers control share ownership can decrease the agency problem between owners and managers. Also, the alignment of interest between the managers and ownerships concentration will improve firm performance. Contradictory, the separation between the ownership concentration and managers will make managers take decision that is will be benefit for them and may harm firm performance. Literately, several studies show that ownerships concentration will increase FP (e.g., Nguyen, 2011). Other like (Wiwattanakantang, 2001) investigated the positive association between ownership concentration and FP in the sample of Thai firms. However, Mak and Kusnadi (2005) find no relation between ownership concentration and firm performance in Malaysia and Singapore, though we propose the following hypothesis.

Hypothesis 1.5 Ownership concentration has a significant effect on firm performance.

Vol.2, No.1, Part 1., Jan. 2021 


\subsubsection{The effect of audit reputation on firm performance}

Choosing the big 4 well-known auditors for auditing firms' financial statements will reduce information asymmetry and improve firm performance (Detthamrong et al., 2017). DeFond and Lennox (2011) argues that international firms choose large auditors for auditing foreign subsidiaries, and have large operations. Therefore, large and multinational firm choose four big auditors to perform better than small firms which will not choose the four big auditors. In summation, better audit quality will improve FP and decision-making process. Thought, we propose a positive effect between FP and audit reputation, and therefore, the following hypotheses.

Hypothesis 1.6 Audit reputation has a significant effect on firm performance

\subsection{Corporate governance and Environmental social responsibility}

Corporate governance is related to the relationship between the enterprise and stakeholders and also the enterprise and society, which propose that high levels of corporate governance structure could safeguard stakeholder's right and ensure social responsibility. Good corporate governance ensures high level of social responsibility disclosure and thereby attracts more investors and achieves sustainable development (Khan and Muttakin, 2013). Therefore, we conclude that the possession of good corporate governance is the basis to undertaking social responsibilities in the organization. 
Adams and Zutshi (2004) have argued that moral responsibility and business interests are the main drivers for the environmental social responsibility. Moreover, Smith, (2002) has conducted a survey for the feasibility of corporate social responsibility CSR criteria it was found that "consumers expect firms to meet high health and safety, worker, human rights, consumer protection, and environment a standards, regardless of where their operations are located" therefore, acting in a social and environmental attitude will give the organization four major benefit, it will attract the talented employee for recruitment, improve the reputation and image for stakeholders, saving cost and effective decision making and finally improve in financial performance. (Adams and Zutshi 2004)

The relationship between the two concepts will results for beneficial synergies (Jamali et al., 2008; Chan et al., 2013) argued that there has been a little discussion about the link between the two variables. Social responsibility activities are affected by the actions and decisions taken by organization; therefore, corporate governance mechanism could be important consideration and determinants of social responsibility (Gibbins et al. 1990; Haniffa and Cooke 2005). Several studies thus far have linked CG with CSR (for example, Johnson and Greening 1999; Jo and Harjoto 2011) have founded a positive association between CSR responsibility and governance mechanism. Also, Beltratti 2005, suggest that CSR and corporate governance are positively related to market value. 


\subsubsection{The effect of board size and environmental social responsibility.}

Different authors have studied the effect of board size and ESR; however, there is no consistent result on the effect on both variables. Agency theory posits that the larger board size has a greater opportunity to mitigate the agency costs by undertaking more socially responsible initiatives, especially during times of crises and regulatory reform (Sadou et al., 2017). Also, Ahmed haji (2013) has argued that larger board has greater knowledge different gender and greater diversity of background that can be useful for the company to gain different ideas about engagement in social activities. Consistent with that a number of previous studies have examined the association between board size and CSR, which have found appositive significant effect between board size and CSR for example Zaid et al. (2019), Barakat et al. (2015), Sadou et al. (2017) and Ahmed Haji (2013). On the other hand, a group literature has argued that small board is peter for monitoring management and improving firm performance for instance, Lakhal (2005) argues that smaller boards can monitor management's actions in an effective manner than Larger boards. Jensen (1993) found that smaller boards size is more likely to make faster and consistent decisions and communicate and coordinate in more efficient and effective way. Therefore, we propose the following hypothesis.

Hypothesis 2.1 Board size has a significant effect on ESR

Vol.2, No.1, Part 1., Jan. 2021 


\subsubsection{The effect of Board independence and environmental social responsibility.}

Till date there is no consistent results to observe whither board independence influences the level of CSR activities of the company. Haniffa and Cooke (2005) argued that board independence might enhance the CSR activities and ensure congruence between a company's activities and its social responsibilities. Other like, Harjoto and Jo (2011) ensure that independent board members are more accountable to the company's shareholder, due to the neutrality of their interest and position. And therefore, it is more expected to have greater focus on meeting the social obligation of the company. Moreover, Khan et al. (2013) and Ullah et al. (2019) have found a positive association between board independence and CSR disclosures. On the other hand, previous research like Chang et al. (2017) observes that independent directors could restrict managers' selfseeking activities that may lead to socially irresponsible decisions. Therefore, we propose the following hypothesis.

Hypothesis 2.2 Board independence has a significant effect on ESR

\subsubsection{The effect of Female directorship and environmental social responsibility.}

Historically, a lot of emerging countries have a big concern on the female empowerment and education and still male dominated. However, recently this is changing due to the role that the woman plays now a day in the whole world. 
Adams and Ferreira, (2009) argues that gender diversity of the board can influence the quality of its monitoring role in the organizations. And inclusion of a female on the board direction might result in better decisions, due to their active role in the board meetings. (Letendre, 2004). Konrad et al., (2008) argues that according to the critical mass theory, the Presence of female on the board is critical to change the board attitude towards CSR reporting. Priviouse studies a positive association between femal directors and CSR for example Ullah et al. (2019) and Orazalin, N. (2019). Other like Majumder et al. (2017) documents a positive and insignificant association between board gender diversity and corporate social disclosures. Also Post et al. (2011) have found that firm with more female director acts in disclosure of more environmental activities. Therefore, we propose the following hypothesis.

Hypothesis 2.3 Female directorship has a significant effect on ESR

\subsubsection{The effect of Role Duality and environmental social responsibility.}

Role duality as defined earlier in the research; it accurses when the one person as the chief executive officer (CEO) is also the chairperson of the board of directors. The role duality of the CEO gives him the power to make decisions which may not take into account the interest of a board set of stakeholders. Consequently, this could minimize the involvement of the firm in the social and environmental activities and disclosures Haniffa and Cooke (2002). Previous studies dominate that role duality have a negative significant effect on the CSR Muttakin et al. (2015) and Giannarakis (2014). Others like Razak and Mustapha (2013) show an insignificant negative association between role duality and CSR disclosures. In addition, Khan et al. (2013) find that role duality does not influence CSR reporting. Therefore, we propose the following hypothesis.

Hypothesis 2.4 Role Duality has a significant effect on ESR

Vol.2, No.1, Part 1., Jan. 2021 


\subsubsection{The effect of Ownership concentration and environmental social responsibility.}

As defined earlier the concentration of the ownership is the proportion of common stock held by the top three shareholders. Such managerial ownership concentration enables the managers of the organization to dominate and take control of all strategic policies of the organization, consequently take the control of all social and environmental behavior and activities required from the company (Ahmed and Siddiqui 2011). From the agency theory point of view, explained later in the research this is referred to as the 'type II' agency problem. Moreover, because of the less public interest and the nature of this company, the management pays less attention to social and environmental activities, and may invest less in the CSR disclosures. Several researches have documented a negative relationship between managerial ownership and the extent of CSR disclosures for example, (Oh et al. 2011; Ghazali 2007). Others like Khan, (2013) have found significant and positive association for export-oriented industries. We therefore, propose the following hypothesis:

Hypothesis 2.5 Ownership concentration has a significant effect on ESR

\subsubsection{The effect of Audit reputation and environmental social responsibility.}

Choosing the big 4 well-known auditors for auditing firms' financial statements will reduce information asymmetry and improve firm performance (Detthamrong et al., 2017). DeFond and Lennox (2011). Consequently, the big 4 well-known auditors may not work in organization that don't possess the environmental and social activities and disclosures. And prefer to work in a sociopolitical environment: therefore, propose the following hypothesis:

Hypothesis 2.6 Audit reputation has a significant effect on ESR हvร

Vol.2, No.1, Part 1., Jan. 2021 


\subsection{Environmental social responsibility and firm performance}

Stakeholders force the organization to engage is social and environmental responsibility. (Grougiou et al., 2016; Perks et al., 2013). Firm communicate through several channel of disclosure such as social, environmental and sustainable reports to reach stakeholder and disclose for tier CSR reports (Perks et al., 2013). The contribution of the organization in CSR activities will shape the way stakeholders perceive the organization (Neu et al., 1998). Perks et al., (2013) has argued that disclosure of CSR reports will increase the perception of the public to the organization and influence the way the stakeholder looks at the firm. Many Firms uses CRS reports to build a good image and reputation with stakeholders at the market (Gray et al., 1995).

CSR reports affect firm value through cost, sales, operations, financing and litigation risk; therefore, disclosure of CSR reports is important for market participants (i.e., shareholders) (Dhaliwal al., 2012). The disclosure of CSR reports will help the shareholders to take important decisions for the futures cash flow, earning and financial information of the organization. Moreover, CSR repotting will provide the firm with a competitive advantage which will influence shareholders. (Jamali et al., 2008).

A number of studies have examined the relationship between CSR and FP (Cochran and Wood, 1984; Aupperle et al., 1985; McGuire et al., 1988; Waddock and Graves, 1997; McWilliams and Siegel, 2000; Orlitzky et al., 2003; Smith, 2003; Ortas et al., 2014) but to date none has clarify a positive or a negative relation between the two variables. The reason of the inconsistency of the correlation between these variables is the differences of measuring CSR and FP, the missing of latent variable in testing the models, and the absence of casualty analysis (Margolis and Walsh, 2003).

Vol.2, No.1, Part 1., Jan. 2021 
Stanwick and Stanwick (1998) have found from the past reviews that there is appositive but week relation between the following variables after the reviewing of 127 studies from period 1972 to 2002: Margolis and Walsh (2003) have reached a positive correlation between the two variables whether the CSR was independent of (109 studies) and dependent of (18 studies). Therefore, we proposed the following hypotheses.

Hypothesis 3: Environmental social responsibility has a significant effect on firm performance.

\subsection{The mediating role of environmental social responsibility.}

In this section, we argue that CG doesn't affect the FP directly but rather affects FP indirectly through environmental and social responsibility. As discussed in the above two Sections 2.2 and 2.3, CG is expected to affect ESR and, also ESR has been found to be influenced with FP, the research now will theoretically question whether the inconsistent results regarding the relationship between the two variables CG and FP might be because the effect of CG on FP is mediated by ESR. Therefore, Consistent with the above relations, we propose the following hypotheses.

Hypothesis 4.1: ESR mediates the relationship between board size and firm performance.

Hypothesis 4.2: ESR mediates the relationship between board independence and firm performance.

Hypothesis 4.3 ESR mediates the relationship between female directorship and firm performance.

Vol.2, No.1, Part 1., Jan. 2021 
Hypothesis 4.4 ESR mediates the relationship between role duality and firm performance.

Hypothesis 4.5 ESR mediates the relationship between ownership concentration and firm performance.

Hypothesis 4.6 ESR mediates the relationship between audit reputation and firm performance.

\section{Research methodology.}

The research population consists of all 228 firms currently listed on the Egyptian Exchange (The Egyptian Exchange website).1 Following Shaker \& Elgiziry (2014), the researcher will employ judgment-sampling technique to select the most active 100 companies in the Egyptian Exchange, which constitute the EGX100 index 2 over the period from 2010 to 2018. EGX100 Index tracks the performance of the 100 active companies, including both the 30 constituent-companies of EGX30 Index and the 70 constituent-companies of EGX70 Index (The Egyptian Exchange website). 3

The year 2011 is considered a formidable year in the history of the Egyptian capital market, where started with the 25th of January revolution. As a result, all market indices retreated, whereas, EGX 30 index decreased by almost $49 \%$, while EGX70 and EGX100 declined by $42 \%$ and $45 \%$, respectively. Moreover, all the traded sectors in the Egyptian market witnessed a significant decline during 2011 (The Egyptian Exchange, the annual report 2011, pp.8-13).4 Therefore, this year will be dropped from the sample period.

\footnotetext{
${ }^{1}$ See, http://www.egx.com.eg/english/ListedStocks.aspx, accessed on 25/08/2017.

${ }^{2}$ See, https://www.decypha.com/en/index/EGX/EGX100, accessed on 25/08/2017.

${ }^{3}$ See, http://www.egx.com.eg/english/OverviewEGX100.aspx?Nav=4, accessed on 25/08/2017.

${ }^{4}$ See, http://www.egx.com.eg/English/Services Reports.aspx, accessed on $25 / 08 / 2017$
} 


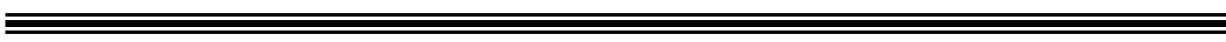

Following, Taha \& Elgiziry (2016), 17 financial firms will be dropped from research sample due to the high leverage characteristics associated with these firms that differ from those of non-financial firms.5 Moreover, to ensure the availability of market data, 17 companies listed on the Egyptian Exchange after 2010 will also be excluded.6

Thus, the final research sample will comprise 66 firms distributed on 23 industries out of the most active 100 companies in the Egyptian Exchange, which constitute the EGX100 index over the period from 2010 to 2018, yielding 528 firm-year observations.

Accounting information as well as market data will be obtained from Decypha platform. Also, the researcher will obtain the weighted average interest rates on less than one-year EGP deposits from the Central Bank of Egypt website. Finally, the normalized environmental and social score will be obtained from the Egyptian Exchange.

\subsection{Measures of study variables}

This section describes research variables and their measures. These variables can be grouped into four categories: the dependent variable (i.e., firm performance), and the independent variable (i.e., corporate governance), as well as potential mediating variables (i.e., environmental social responsibility) in addition to a set of control variables.

\footnotetext{
${ }^{5}$ See, https://www.decypha.com/en/fundamental-screener, accessed on 25/08/2017. ${ }^{6} \mathrm{See}$, htto://www.egx.com.eg/english/listedStocks.aspox, accessed on 25/08/2017. हVर
}

Vol.2, No.1, Part 1., Jan. 2021 


\subsubsection{Dependent variable: Firm performance}

The research dependent variable is firm performance is measured by return on equity (ROE), return on asset (ROA) and Tobin's Q. following Chen et al. (2005) and Bhabra (2007) return on equity (ROE) is computed as the ration of earnings before interest and tax to equity. ROE has been trusted by all shareholders, it is used to be a measure for the investors to show how much profit can be generated form the firm, using the money invested from its shareholders (Epps and Cereola, 2008). We also use return on assets (ROA), measured as the ratio of earnings before interest and taxes to total assets. ROA show the amount of earning that have been generated from invested capital asset, it incorporates firm performance (Epps and Cereola, 2008). Finally, we follow (Kaplan and Zingales, 1997) to use Tobin's $Q$ as a proxy for firm value. Tobin's $Q$ is used to calculate the market performance. Tobin's q ratio; ratio of market value of equity and book value of debt to book value of total assets. (Lang and Stulz, 1994).

\subsubsection{Independent variable: Corporate governance}

Following Chen et al, 2005; Bhagat and Bolton (2008), Nguyen, 2011 the researcher will use six measures of CG (Ownership concentration, Female directorship, Role Duality, Board independence, Board size and Audit reputation) where, Ownership concentration (OWN_CONCENTRATION) is the proportion of common stock held by the top three shareholders. Female directorships (BD_WOMEN) are the ratio of the number of female directors to the number of all directors. Role duality (CEO_DUAL) is a dummy variable, which takes a value of one if the CEO is also the chairperson of the board, and zero otherwise. Board

Vol.2, No.1, Part 1., Jan. 2021 
independence (BD_IND) is computed as the ratio of the number of independent directors to the number of all directors. Board size (BD_SIZE) is the number of all board directors. Audit reputation (AUD_REP) is a binary variable that indicates whether a firm uses one of top four auditing firms and takes a value of one where a firm's auditor is one of the big four auditing firms, and zero otherwise the big four auditing firm in Egypt is KPMG (hazem Hassan), Ernst and young, ,Price water house Coopers (fared Mansour), Deloitte (Saleh and Barsom and abd el axix).

\subsubsection{Potential mediating variable: Environmental social responsibility.}

The ESR factor is measured using the S\&P/EGX ESG ratings Published index. It is an index based purely on quantitative factors rather than subjective ones. For the first time, environmental, social and corporate governing factors have been extensively quantified and translated into a series of scores measuring securities in the universe of publicly traded Egyptian companies. The S\&P/EGX ESG Index constituents are derived is the top 100 Egyptian companies by ESG scores, listed on the Egyptian Stock Exchange (EGX), (The Egyptian Exchange website).

All 100 companies were chosen after being subjected to a screening process which incorporates environmental, social and governance (ESG) indicators (The Egyptian Exchange website). 
The screening process ultimately yields a score, or an evaluation, for each of the companies in the universe. The evaluation process seeks information relating to companies' disclosure of the ESG screen indicators available in the public domain, such as a company's annual report, Web site, bulletins and/or the disclosure made on the stock exchanges.

Therefore, ESR is measured as the natural logarithm of the normalize ESR score plus ESR score qualitative (The Egyptian Exchange website).

\subsubsection{Firm control variables}

Following Detthamrong et al., (2017) the research will include a large set of control variables to mitigate the outside effects that may affect the results and also firm-specific characteristics that might influence the firm's ESR and firm performance. More specifically, the research will include firm size (LN_TA) which is measured by the natural logarithm of total assets. market-to-book ratio (MBV), which is computed as the ratio of the market value of common equity to the book value of common equity, Firm age (LN_FIR_AGE) and is measured by the natural logarithm of the number of years since the company is listed. Capital investment (CAP_EX_TA), which is computed as the ratio of capital expenditure to one-period lagged total assets. Current ratio (CUR_RAT) and is calculated as the ratio of current assets to current liabilities. The cash flow to total assets Ratio (CASH_TA) and is measured by the cash flow to total assets Ratio. And fixed assets ratio (FIX_AS_RAT) and is computed the ratio of net property, plant, and equipment to total asset.

Vol.2, No.1, Part 1., Jan. 2021 


\section{2 design of study model}

In the following section, the previously discussed hypothesizes is tested through a static panel data model using generalized least square (GLS) estimation. The research has arrayed the collected data into an unbalanced panel dataset and utilizes Eviews statistical software to conduct the analyses.

The assumption of no Multicoloniality is tested using a correlation matrix to check for linear relationship between the independent variables. (Please see Table1)

A pooled regression models were tested using both fixed and random effects, to determine the most appropriate model using Hausman tests for each model (Hausman, 1978) A large and significant Hausman statistic determined that the use of fixed effects panel regression models were most appropriate.

Additionally, the research examined the relationships from both a cross-sectional and a longitudinal perspective. From a cross-sectional perspective by developing a GLS Regression model.

The problem of autocorrelation will be cured by using Cochrane Orcutt method after indication of the positive or negative autocorrelation by (Durbin Watson statistic). The Cochrane-Orcutt method suggests estimating the residuals form the original model then regressing the residual on Lagged residuals for 1 time period. 
Scientific Journal for Financial and Commercial Studies and Researches

Dr. Mohamed EL-Hindawy; Dr. Amir Shousha \& Ahmed Rady

Further, the difference between each variable and its one-time lagged values multiplied by the regression coefficient of the lagged residual. Finally, the GLS method is applied to account for the non-constant variations in the residuals (the problem of hetroskadistity)

Heteroscedasticity is a serious problem that can affect the estimate of the random and fixed effect in the model. The existence of these problem means that the standards errors associated with each regression coefficient will be not correct (Gujarati, 2003). Therefore, a Generalized least square (GLS) method is applied to corrects for Heteroscedasticity in all models (Hausman, 1978).

\subsubsection{The conceptual Model (Framework)}

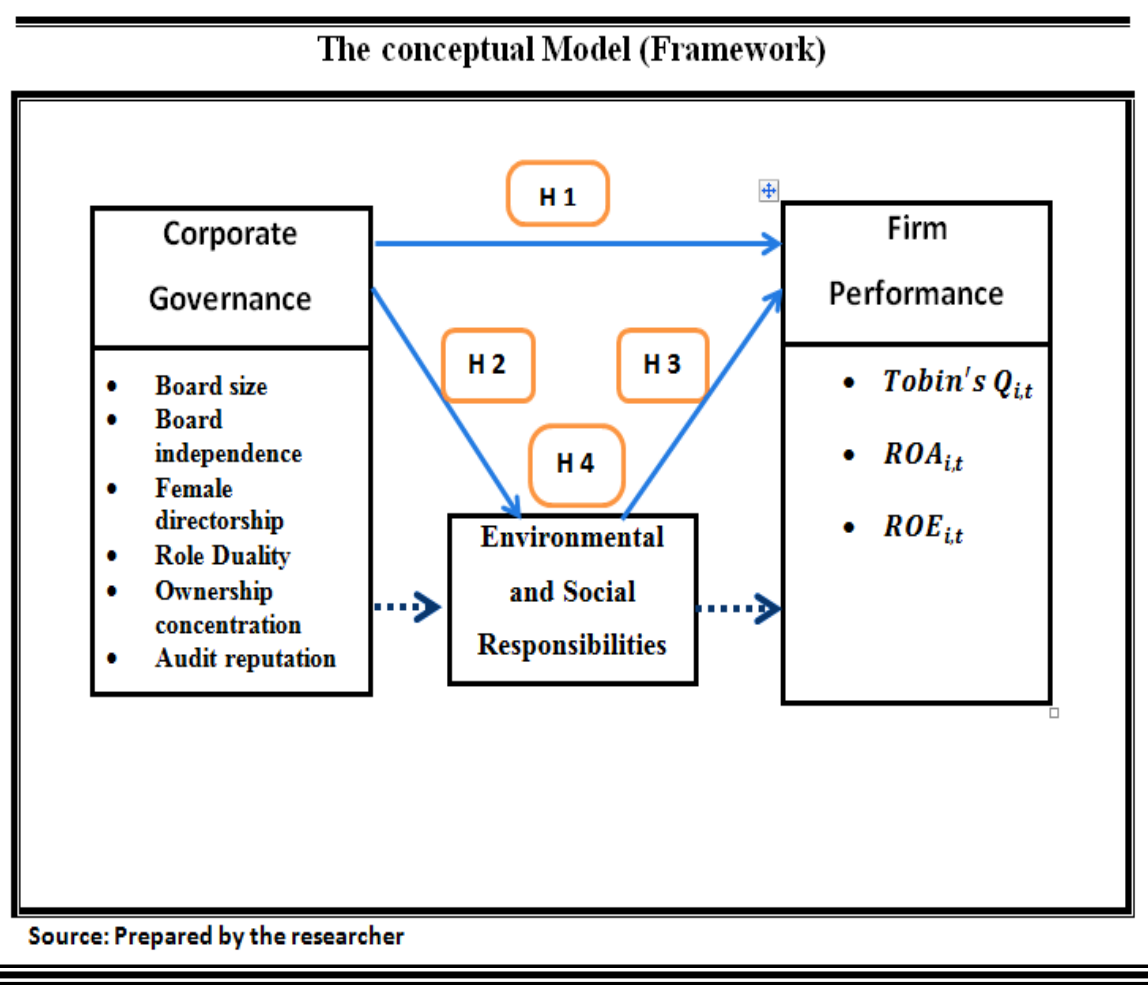

Vol.2, No.1, Part 1., Jan. 2021 
Scientific Journal for Financial and Commercial Studies and Researches

Dr. Mohamed EL-Hindawy; Dr. Amir Shousha \& Ahmed Rady

Model 1

$$
\begin{aligned}
& \text { ROA }_{i, t}=\beta_{1,0}+\beta_{1,1} \text { AUD_REP }+\beta_{1,2} \text { BD_INDP }+\beta_{1,3} \text { BD_SIZE }+\beta_{1,4} \text { BD_WOMEN } \\
& +\beta_{1,5} \text { OWN_CONCENTRATION }+\beta_{1,6} \text { CEO_DUAL }+\beta_{1,7} \text { CAP_EX_TA } \\
& +\beta_{1,8} \text { CASH_TA }+\beta_{1,9} \text { CUR_RAT }+\beta_{1,10} \text { FIX_AS_RAT } \\
& +\beta_{1,11} \text { LN_FIR_AGE }+\beta_{1,12} \text { LN_TA }+\beta_{1,13} \text { MBV }+\varepsilon_{1, i, t} \\
& R O E_{i, t}=\beta_{2,0}+\beta_{2,1} A U D \_R E P+\beta_{2,2} B D \_I N D P+\beta_{2,3} B D \_S I Z E+\beta_{2,4} B D \_W O M E N \\
& +\beta_{2,5} \text { OWN_CONCENTRATION }+\beta_{2,6} C E O \_D U A L+\beta_{2,7} C A P \_E X \_T A \\
& +\beta_{2,8} C A S H \_T A+\beta_{2,9} C U R \_R A T+\beta_{2,10} F I X \_A S_{-} R A T \\
& +\beta_{2,11} L N_{-} F I R_{-} A G E+\beta_{2,12} L N_{-} T A+\beta_{2,13} M B V+\varepsilon_{2, i, t}
\end{aligned}
$$

Tobin's $Q_{i, t}=\beta_{3,0}+\beta_{3,1} A U D \_R E P+\beta_{3,2}$ BD_INDP $+\beta_{3,3}$ BD_SIZE

$+\beta_{3,4}$ BD_WOMEN $+\beta_{3,5}$ OWN_CONCENTRATION $+\beta_{3,6}$ CEO_DUAL

$+\beta_{3,7}$ CAP_EX_TA $+\beta_{3,8}$ CASH_TA $+\beta_{3,9}$ CUR_RAT

$+\beta_{3,10}$ FIX_AS_RAT $+\beta_{3,11}$ LN_FIR_AGE $+\beta_{3,12}$ LN_TA $+\beta_{3,13}$ MBV

$+\varepsilon_{3, \mathbf{i}, \mathrm{t}}$

Model 2

$$
\begin{aligned}
\text { ROA }_{i, t}=\beta_{4,0} & +\beta_{4,1} \text { ESR_SCORE }+\beta_{4,2} \text { CAP_EX_TA }+\beta_{4,3} \text { CASH_TA }+\beta_{4,4} \text { CUR_RAT } \\
& +\beta_{4,5} \text { FIX_AS_RAT }+\beta_{4,6} \text { LN_FIR_AGE }+\beta_{4,7} \text { LN_TA }+\beta_{4,8} \text { MBV }+\varepsilon_{4, i, t}
\end{aligned}
$$

$$
\begin{aligned}
\text { ROE }_{i, t}= & \beta_{5,0} \\
+ & \beta_{5,1} \text { ESR_SCORE }+\beta_{5,2} \text { CAP_EX_TA }+\beta_{5,3} \text { CASH_TA }+\beta_{5,4} \text { CUR_RAT } \\
& +\beta_{5,5} \text { FIX_AS_RAT }+\beta_{5,6} \text { LN_FIR_AGE }+\beta_{5,7} \text { LN_TA }+\beta_{5,8} \text { MBV }+\varepsilon_{5, i, t}
\end{aligned}
$$


Model 3

$$
\begin{aligned}
& \text { Tobin's } Q_{i, t}=\beta_{6,0}+\beta_{6,1} \text { ESR_SCORE }+\beta_{6,2} \text { CAP_EX_TA }+\beta_{6,3} \text { CASH_TA } \\
& +\beta_{6,4} \text { CUR_RAT }+\beta_{6,5} \text { FIX_AS_RAT }+\beta_{6,6} \text { LN_FIR_AGE }+\beta_{6,7} \text { LN_TA } \\
& +\beta_{6,8} \mathrm{MBV}+\varepsilon_{6, \mathrm{i}, \mathrm{t}} \\
& \mathrm{ESR}_{\mathrm{i}, \mathrm{t}}=\beta_{7,0}+\beta_{7,1} \mathrm{AUD} \_ \text {REP }+\boldsymbol{\beta}_{7,2} \text { BD_INDP }+\boldsymbol{\beta}_{7,3} \text { BD_SIZE }+\boldsymbol{\beta}_{7,4} \text { BD_WOMEN } \\
& +\beta_{7,5} \text { OWN_CONCENTRATION }+\beta_{7,6} \text { CEO_DUAL }+\beta_{7,7} \text { CAP_EX_TA } \\
& +\beta_{7,8} \text { CASH_TA }+\beta_{7,9} \text { CUR_RAT }+\beta_{7,10} \text { FIX_AS_RAT } \\
& +\beta_{7,11} \text { LN_FIR_AGE }+\beta_{7,12} \text { LN_TA }+\beta_{7,13} \text { MBV }+\varepsilon_{7, i, t}
\end{aligned}
$$

\section{Model 4}

$$
\begin{aligned}
& \mathrm{ROA}_{\mathrm{i}, \mathrm{t}}=\beta_{8,0}+\beta_{8,1} \text { ESR }+\beta_{8,2} \text { AUD_REP }+\beta_{8,3} \text { BD_INDP }+\beta_{8,4} \text { BD_SIZE } \\
& +\beta_{8,5} \text { BD_WOMEN }+\beta_{8,6} \text { OWN_CONCENTRATION }+\beta_{8,7} \text { CEO_DUAL } \\
& +\beta_{8,8} \text { CAP_EX_TA }+\beta_{8,9} \text { CASH_TA }+\beta_{8,10} \text { CUR_RAT } \\
& +\beta_{8,11} \text { FIX_AS_RAT }+\beta_{8,12} \text { LN_FIR_AGE }+\beta_{8,13} \text { LN_TA }+\beta_{8,14} \text { MBV } \\
& +\varepsilon_{8, i, t}
\end{aligned}
$$




$$
\begin{aligned}
& \mathrm{ROE}_{\mathrm{i}, \mathrm{t}}=\beta_{\mathbf{9 , 0}}+\beta_{\mathbf{9 , 1}} \mathrm{ESR}+\beta_{\mathbf{9}, \mathbf{2}} \text { AUD_REP }+\beta_{\mathbf{9}, 3} \text { BD_INDP }+\beta_{\mathbf{9}, \mathbf{4}} \text { BD_SIZE } \\
& +\beta_{9,5} \text { BD_WOMEN }+\beta_{9,6} \text { OWN_CONCENTRATION }+\beta_{9,7} \text { CEO_DUAL } \\
& +\beta_{9,8} \text { CAP_EX_TA }+\beta_{9,9} \text { CASH_TA }+\beta_{9,10} \text { CUR_RAT } \\
& +\beta_{9,11} \text { FIX_AS_RAT }+\beta_{9,12} L N_{-} \text {FIR_AGE }+\beta_{9,13} L N_{-} \text {TA }+\beta_{9,14} \text { MBV } \\
& +\varepsilon_{9, \mathbf{i}, \mathrm{t}}
\end{aligned}
$$

$$
\begin{aligned}
\text { Tobin's } Q_{i, t}= & \beta_{10,0}+\beta_{10,1} \text { ESR }+\beta_{10,2} \text { AUD_REP }+\beta_{10,3} \text { BD_INDP }+\beta_{10,4} \text { BD_SIZE } \\
& +\beta_{10,5} \text { BD_WOMEN }+\beta_{10,6} \text { OWN_CONCENTRATION }+\beta_{10,7} \text { CEO_DUAL } \\
& +\beta_{10,8} \text { CAP_EX_TA }+\beta_{10,9} \text { CASH_TA }+\beta_{10,10} \text { CUR_RAT } \\
& +\beta_{10,11} \text { FIX_AS_RAT }+\beta_{10,12} \text { LN_FIR_AGE }+\beta_{10,13} \text { LN_TA }+\beta_{10,14} \text { MBV } \\
& +\varepsilon_{10, i, t}
\end{aligned}
$$

The a above part represents all the descriptive statistics of the variables presented, correlations between the dependent and independent variables will be described and a regression analysis done to test the stated hypothesis. We will denote $\beta_{1, j}$ the jth parameter in the lth model and $\varepsilon_{1, i, t}$ is the error for the lth model at cross section $\mathrm{i}$ and time $\mathrm{t}$.

\section{5- Statistical analysis}

In this section we present the statistical analysis, this analysis will be divided into two parts. The first part shows the descriptive measures for the redefined variables and the second part shows a panel data regression result. 
Scientific Journal for Financial and Commercial Studies and Researches

Dr. Mohamed EL-Hindawy; Dr. Amir Shousha \& Ahmed Rady

\section{1 descriptive analyses}

The following section will present the correlation matrix for all variables and summary measures for all variables. Table 1 reports the correlation coefficients between key variables for a sample of 528 firm-year observations covering the period 2010-2018. This table reports correlation coefficients among variables (numbers in parentheses are p-values for correlation coefficients). (Correlation is significant at level 0,01, 0, 05 and o.10). 
Scientific Journal for Financial and Commercial Studies and Researches

Dr. Mohamed EL-Hindawy; Dr. Amir Shousha \& Ahmed Rady

\begin{tabular}{|c|c|c|c|c|c|c|c|c|c|c|c|c|c|c|c|c|c|}
\hline & CAP_EX_TA & CASH_TA & CUR_RAT & FIX_AS_RAT & LN_FIR_AGE & LN_TA & MBV & AUD_REP & BD_INDP & BD_SIZE & BD_WOMEN & CEO_DUAL & \begin{tabular}{|l|} 
OWN_CONC \\
ENTRATION
\end{tabular} & ESR_SCORE & $\mathrm{ROA}$ & ROE & TOBINS_Q \\
\hline CAP_EX_TA & 1.000 & & & & & & & & & & & & & & & & \\
\hline CASH_TA & 0.007 & 1.000 & & & & & & & & & & & & & & & \\
\hline CUR_RAT & -0.005 & -0.065 & 1.000 & & & & & & & & & & & & & & \\
\hline FIX_AS_RAT & -0.052 & 0.181 & -0.037 & 1.000 & & & & & & & & & & & & & \\
\hline LN_FIR_AGE & 0.033 & -0.071 & -0.021 & -0.101 & 1.000 & & & & & & & & & & & & \\
\hline LN_TA & -0.01 & 0.220 & -0.252 & -0.047 & -0.126 & 1.000 & & & & & & & & & & & \\
\hline MBV & -0.014 & 0.268 & 0.029 & -0.067 & -0.114 & 0.027 & 1.0000 & & & & & & & & & & \\
\hline AUD_REP & -0.035 & -0.05 & -0.086 & 0.101 & -0.059 & 0.279 & -0.11 & 1.000 & & & & & & & & & \\
\hline BD_INDP & 0.019 & -0.076 & -0.027 & 0.082 & -0.079 & 0.145 & -0.15 & 0.254 & 1.000 & & & & & & & & \\
\hline BD_SIZE & 0.422 & 0.087 & -0.045 & -0.079 & 0.006 & 0.138 & 0.091 & -0.053 & -0.063 & 1.000 & & & & & & & \\
\hline BD_WOMEN & -0.014 & 0.100 & 0.053 & 0.127 & 0.001 & -0.161 & 0.138 & -0.014 & -0.022 & 0.091 & 1.000 & & & & & & \\
\hline CEO_DUAL & 0.073 & 0.110 & 0.066 & -0.029 & -0.086 & -0.115 & 0.071 & -0.207 & -0.076 & 0.057 & 0.188 & 1.000 & & & & & \\
\hline $\begin{array}{l}\text { OWN_CONCE } \\
\text { NTRATION }\end{array}$ & 0.068 & 0.121 & -0.256 & 0.101 & 0.314 & 0.242 & -0.003 & 0.016 & -0.065 & -0.007 & -0.082 & -0.08 & 1.000 & & & & \\
\hline ESR_SCORE & -0.034 & 0.193 & -0.043 & 0.029 & 0.035 & 0.231 & 0.035 & 0.208 & 0.140 & 0.034 & 0.106 & 0.004 & 0.131 & 1.000 & & & \\
\hline $\mathrm{ROA}$ & 0.053 & 0.632 & 0.020 & -0.034 & -0.025 & 0.234 & 0.332 & 0.001 & -0.086 & 0.116 & 0.110 & 0.119 & 0.018 & 0.115 & 1.000 & & \\
\hline ROE & 0.014 & 0.025 & -0.043 & -0.072 & 0.048 & 0.036 & -0.086 & -0.026 & -0.024 & 0.093 & 0.148 & 0.087 & 0.107 & 0.122 & 0.160 & 1.000 & \\
\hline TOBINS_Q & -0.068 & -0.172 & 0.022 & 0.056 & -0.064 & -0.327 & 0.032 & -0.037 & -0.015 & -0.075 & 0.044 & 0.037 & -0.111 & 0.004 & -0.264 & 0.006 & 1.000 \\
\hline
\end{tabular}

Vol.2, No.1, Part 1., Jan. 2021 
Table 1 presents correlation coefficients of key variables for the final sample of 528 observations. As the correlation coefficients between explanatory variables are generally below 0.50 , which indicates the non-existence of sever multicollinearity. The correlation between ROE and ROA is $(r=0.16), \mathrm{ROE}$ and robins' $\mathrm{Q}$ is $(\mathrm{r}=0.006)$, thereby indicating that they cannot be used almost interchangeably as a proxy for FP. However, each of them will be modeled separately. Looking at correlation coefficients between ESR and CG variables, we find that the magnitude is small $(\mathrm{r}<0.2)$. In addition, when looking at correlation coefficients between FP and CG variables, we also find that the magnitude is also small $(\mathrm{r}<0.14)$. However, these values are the partial correlation values which will increase by including other explanatory variables.

Table 2 Descriptive statistics on key variables

\begin{tabular}{|llllll|}
\hline & Mean & Median & Maximum & $\begin{array}{l}\text { Minimu } \\
\text { m }\end{array}$ & $\begin{array}{l}\text { Std. } \\
\text { Dev. }\end{array}$ \\
\hline CAP_EX_TA & 0.023 & 0.001 & 2.391 & -1.066 & 0.177 \\
CASH_TA & 0.050 & 0.039 & 2.185 & -0.910 & 0.163 \\
CUR_RAT & 2.589 & 1.520 & 61.85 & 0.336 & 5.552 \\
FIX_AS_RAT & 0.277 & 0.249 & 1.523 & 0.001 & 0.215 \\
LN_FIR_AGE & 2.666 & 2.833 & 4.060 & 0.000 & 0.578 \\
LN_TA & 20.979 & 20.994 & 24.728 & 17.010 & 1.625 \\
MBV & 1.864 & 0.906 & 43.418 & -38.688 & 5.310 \\
BD_INDP & 0.092 & 0.050 & 0.818 & 0.000 & 0.137 \\
BD_SIZE & 8.625 & 8.000 & 77.000 & 4.000 & 4.914 \\
BD_WOMEN & 0.072 & 0.066 & 0.444 & 0.000 & 0.087 \\
OWN_CONCENTRAT & 53.591 & 51.991 & 99.680 & 0.050 & 18.377 \\
ION & & & & & \\
ESR_SCORE & 41.158 & 39.455 & 68.333 & 30.775 & 7.163 \\
ROA & 3.8573 & 3.023 & 40.660 & -124.66 & 11.32 \\
ROE & 10.716 & 8.030 & 397.96 & -173.84 & 34.37 \\
TOBINS_Q & 1.002 & 0.556 & 21.429 & 0.027 & 2.002 \\
\hline
\end{tabular}

Vol.2, No.1, Part 1., Jan. 2021 
This table presents a descriptive statistic for key variables for the sample of 528 firm-year observations over the period 2010-2018.

Table 2 presents the descriptive statistics for the final sample of 528 firmyear observations over the period from 2010-2018. The mean, the median and the standard deviation values of AUD_REP is 0.213, 0.000 and 0.408 , respectively. The mean, the median and the standard deviation values of BD_INDP is 0.092, 0.0504and 0.137, respectively. The mean, the median and the standard deviation values of ESR_SCORE is 41.158, 39.455 and 7.163 respectively, which indicates that the environmental social responsibility score values are around 41.

\subsection{Empirical results}

\subsubsection{The effect of corporate governance on firm performance}

In this section, we display the results of the effects of CG mechanisms on FP. Table 3 presents panel GLS regression where the dependent variable is FP. Firm-fixed effects and year fixed effects are included in all models. We include seven control variables in the model.

Vol.2, No.1, Part 1., Jan. 2021 
Scientific Journal for Financial and Commercial Studies and Researches

Dr. Mohamed EL-Hindawy; Dr. Amir Shousha \& Ahmed Rady

Table 3 reports panel GLS regressions of firm performance

\begin{tabular}{|c|c|c|c|c|c|c|}
\hline \multirow[b]{2}{*}{ Independent Variable } & \multicolumn{2}{|l|}{ ROA } & ROE & \multicolumn{3}{|c|}{ TOBINS_Q } \\
\hline & Coefficient & Prob. & Coefficient & Prob. & Coefficient & Prob. \\
\hline$C$ & -27.410 & 0.0000 & -143.81 & 0.0000 & 2.453 & 0.0006 \\
\hline$A U D_{-} R E P$ & -6.712 & $0.0095 * * *$ & -8.424 & 0.4577 & -0.619 & 0.2398 \\
\hline$B D \_I N D P$ & 0.371 & 0.4469 & 2.285 & 0.1165 & -0.355 & $0.000 * * *$ \\
\hline BD_SIZE_ & -0.017 & 0.2300 & 0.389 & $0.0064 * * *$ & 0.001 & 0.1785 \\
\hline BD_WOMEN & 2.595 & $0.0646^{*}$ & 4.172 & 0.5374 & 0.282 & $0.0864 *$ \\
\hline OWN_CONCENTRATION_ & -0.020 & $0.0100 * * *$ & -0.036 & 0.1510 & -0.002 & $0.0185^{* *}$ \\
\hline CEO_DUAL_ & -1.567 & $0.0000 * * *$ & 4.860 & $0.0001 * * *$ & 0.153 & $0.000 * * *$ \\
\hline CAP_EX_TA & 0.097 & 0.6922 & -0.062 & 0.9612 & 0.000 & 0.9933 \\
\hline CASH_tA & 14.782 & $0.0000 * * *$ & -3.576 & 0.5651 & -0.456 & $0.0006 * * *$ \\
\hline$C U R_{-} R_{A} A T_{-}$ & 0.250 & $0.0020 * * *$ & 0.177 & 0.2933 & 0.000 & 0.9736 \\
\hline$F I X \_A S \_R A T$ & -8.919 & $0.0000 * * *$ & 10.915 & $0.0086 * * *$ & 0.171 & $0.0977 *$ \\
\hline$L N_{-} F I R \_A G E_{-}$ & -0.457 & 0.2409 & 1.522 & 0.2966 & 0.506 & $0.0000 * * *$ \\
\hline$L N_{-} T A_{-}$ & 2.510 & $0.0000 * * *$ & 11.25 & $0.0000 * * *$ & -0.211 & $0.0002 * * *$ \\
\hline$M \bar{B} V_{-}$ & 0.3082 & $0.0000 * * *$ & -2.997 & $0.0000 * * *$ & 0.095 & $0.0000 * * *$ \\
\hline Adjusted R-squared & \multicolumn{2}{|c|}{0.908} & \multicolumn{2}{|c|}{0.886} & \multicolumn{2}{|c|}{0.758} \\
\hline$F$-statistic & \multicolumn{2}{|c|}{58.76} & \multicolumn{2}{|c|}{46.61} & \multicolumn{2}{|c|}{19.34} \\
\hline $\operatorname{Prob}(F$-statistic) & \multicolumn{2}{|c|}{0.000} & \multicolumn{2}{|c|}{0.000} & \multicolumn{2}{|c|}{0.000} \\
\hline
\end{tabular}

This table reports panel GLS regressions of firm performance. The dependent variable is firm performance, which is measured by ROA, ROE and Tobin's Q, *, $* *$, and $* * *$ represent statistical significance at the $10 \%, 5 \%$, and $1 \%$ levels, respectively

The results suggest that in model (1A), only female directorship is positively significant with ROA, which has a value of coefficient of (2.595) and prob of (0.0646). And these finding describe that female directors are associated with higher firm performance; female directors might have better communication and managerial skills than their male counterparts. Which will result in better decisions in the managerial level and therefore enhances firm performance.

Vol.2, No.1, Part 1., Jan. 2021 
This finding is consistent with Erhardt et al. (2003) who find a positive significant in their study of director diversity on firm performance. Also, García-Meca et al. (2015) have found that board diversity improves firm performance in their study of the sample of banks in nine counties (Canada, France, Germany, Italy, the Netherlands, Spain, Sweden, the UK, and the US).

Moreover, audit reputation, ownership concentration and role duality are significantly but negatively related to ROA. Audit reputation has the value of coefficient (-6.712) and Significant level. (0.0095) which indicate a negative significant relation between audit reputation and ROA and by interpreting this finding we find that due to the high cost of the BIG 4 well-known auditor, this will lead to a negative effect on the profitability of the company.

Going to Ownership concentration we find a result of coefficient (-0.020) and Significant level. (0.0100) which indicate a negative significant relation between ownership concentration and ROA and this finding inconsistent with others research like Maury, (2006) who argue that the ownership concentration decreases agency problem and therefore it will enhance firm performance. However, by interpreting these finding we propose that the alignments of interest in a wrong decision between managers and ownership concentration may lead to deterioration of firm performance.

The findings of the role duality show a coefficient $(-1.567)$ and Significant level. (0.0000) which indicate a negative significant relation between role duality and ROA and these results is consistent with Haniffa and Hudaib (2006) who find a negative impact of role duality on firm performance in Malaysia. Also, Chen et al. (2005) in their study of Hong Kong from period 19951998. On the other hand, only board independence and board size are not significant with ROA.

Vol.2, No.1, Part 1., Jan. 2021 
Model (1B) shows a positive and significant relation in only two variables role duality and board size. The finding of role duality shows a coefficient (4.860) and Significant level. (0.0001) and this indicate a positive significant relation between role duality and ROE. And by interpreting these findings, we see the duality of the CEO might improve decision making process and speed the decision making in fast changing environment.

Going to board size the results shows a coefficient (0.389) and Significant level. (0.0064) which indicate a positive significant relation between board size and ROE the results are consistent with Anderson, (2004) who argued that more board of directors means more knowledge and experience and also more accurate and effective decisions making. On the other hand, all other variables concerning audit reputation, ownership concentration, female directorship and board independency are not significantly related with ROE.

In model (1C) role duality and female directorship are positively and statistically significant to Tobin's Q. role duality findings shows a coefficient (0.153) and Significant level. (0.000) which indicates a positive significant relation between role duality and Tobin's $\mathrm{Q}$ and this as argued before that the duality of the CEO might improve decision making process and speed the decision making in a fast-changing environment.

Also, female directorship findings show a coefficient (0.282) and Significant level. (0.0864). This finding is consistent with Erhardt et al. (2003) who find a positive significant in their study of director diversity on firm performance. Also, García-Meca et al. (2015) have found that board diversity improves firm performance in their study of the sample of banks in nine counties (Canada, France, Germany, Italy, the Netherlands, Spain, Sweden, the UK, and the US).

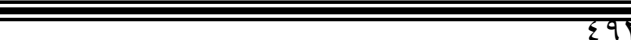

ह9ा

Vol.2, No.1, Part 1., Jan. 2021 
However, board independence shows a coefficient of (-0.355) and Significant level. of (0.000) and ownership concentration shows coefficient of $(-0.002)$ and Significant level. Of (0.0185) are statistically significant but negatively related to Tobin's However, board size, and audit reputation, is not statistically significant with Tobin's Q.

Table 4 reports the summary of hypotheses 1 result.

\begin{tabular}{llll}
\hline Hypothesis results & ROA & ROE & TOBINS_Q \\
\hline $\begin{array}{l}\text { Hypothesis.1.1 Audit reputation has a significant effect } \\
\text { on firm performance }\end{array}$ & Accept & Reject & Reject \\
$\begin{array}{l}\text { Hypothesis.1.2 Board independence has a significant } \\
\text { effect on firm performance }\end{array}$ & Reject & Reject & Accept \\
$\begin{array}{l}\text { Hypothesis.1.3 Board size has a significant effect on } \\
\text { firm performance }\end{array}$ & Reject & Accept & Reject \\
$\begin{array}{l}\text { Hypothesis.1.4 Female directorship has a significant } \\
\text { effect on firm performance }\end{array}$ & Accept & Reject & Accept \\
$\begin{array}{l}\text { Hypothesis.1.5 Ownership concentration has a } \\
\text { significant effect on firm performance }\end{array}$ & Accept & Reject & Accept \\
$\begin{array}{l}\text { Hypothesis. } 1.6 \text { Role Duality has a significant effect on } \\
\text { firm performance }\end{array}$ & Accept & Accept & Accept \\
\hline
\end{tabular}

ह9ร

Vol.2, No.1, Part 1., Jan. 2021 


\subsection{The effect of corporate governance on ESR.}

In this section, we display a panel GLS regression where the dependent variable is ESR score. Firm-fixed effects and year fixed effects are included in the models.to test the direct effect of CG on ESR score; we include seven control variables in the model.

Table 5 reports panel GLS regressions of ESR score

\begin{tabular}{|c|c|c|}
\hline \multirow{2}{*}{$\begin{array}{l}\text { Dependent Variable } \\
\text { independent Variable }\end{array}$} & \multicolumn{2}{|c|}{ ESR_SCORE } \\
\hline & Coefficient & Prob. \\
\hline $\mathrm{C}$ & 30.281 & 0.0010 \\
\hline AUD_REP_ & 5.726 & $0.0042 * * *$ \\
\hline BD_INDP_ & -0.740 & 0.1273 \\
\hline BD_SIZE_ & 0.006 & 0.6520 \\
\hline BD_WOMEN_ & -0.789 & 0.5943 \\
\hline OWN_CONCENTRATION_ & 0.025 & $0.0111 * *$ \\
\hline CEO_DUAL_ & 0.517 & $0.0373 * *$ \\
\hline CAP_EX_TA_ & -0.426 & 0.2734 \\
\hline CASH_TA_ & 1.477 & $0.0001 * * *$ \\
\hline CUR_RAT & 0.027 & $0.0020 * * *$ \\
\hline FIX_AS_RATT_ & 3.016 & $0.0138 * *$ \\
\hline LN_FIR_AGE_- & 3.183 & $0.0000 * * *$ \\
\hline LN_TA_ & -0.958 & 0.1633 \\
\hline $\mathbf{M B V}_{-}$ & 0.091 & $0.0974^{*}$ \\
\hline Adjusted R-squared & 0.681 & \\
\hline F-statistic & 13.49 & \\
\hline Prob(F-statistic) & 0.000 & \\
\hline
\end{tabular}

This table reports panel GLS regressions of ESR score. The dependent variable is ESR score, which is measured by using the S\&P/EGX ESG ratings Published index. *, **, and $* * *$ represent statistical significance at the $10 \%, 5 \%$, and $1 \%$ levels, respectively.

Vol.2, No.1, Part 1., Jan. 2021 
The results suggest that ownership concentration, shows a coefficient of (0.025) and Significant level. (0.0111), audit reputation shows a coefficient of (5.726) and Significant level. of (0.0042) and role duality shows a coefficient of (0.517) and Significant level. of (0.0373) are positively and statistically significant with ESR score.

And by interpreting the following finding we propose that good corporate governance results in positive environmental and social responsibilities, and this finding are consistent with (Khan and Muttakin, 2013) who propose that high levels of corporate governance structure could safeguard stakeholder's right and ensure social responsibility. Good corporate governance ensures high level of social responsibility disclosure and thereby attracts more investors and achieves sustainable development. Therefore, we conclude that the possession of good corporate governance is the basis to undertaking social responsibilities in the organization. On the other hand, board independence, board size and female directorship is not significant with ESR score.

Table 6 reports the summary of hypotheses 2 results.

\begin{tabular}{|c|c|}
\hline Hypothesis results & $\begin{array}{l}\text { ESR } \\
\text { score }\end{array}$ \\
\hline Hypothesis.2.1 Audit reputation has a significant effect on ESR score & Accept \\
\hline Hypothesis.2.2 Board independence has a significant effect on ESR score & Reject \\
\hline Hypothesis.2.3 Board size has a significant effect on ESR score & Reject \\
\hline Hypothesis.2.4 Female directorship has a significant effect on ESR score & Reject \\
\hline $\begin{array}{l}\text { Hypothesis. } 2.5 \text { Ownership concentration has a significant effect on ESR } \\
\text { score }\end{array}$ & Accept \\
\hline Hypothesis.2.6 Role Duality has a significant effect on ESR score & Accept \\
\hline
\end{tabular}

Vol.2, No.1, Part 1., Jan. 2021 


\subsubsection{The effect of ESR on firm performance}

In this section, we display our empirical results regarding the effects of ESR score on FP. Table 7 Represents panel GLS regression where the dependent variable is the FP. Firm-fixed effects and year fixed effects are included in the models.to test the direct effect of ESR score on FP we include seven control variables in the model.

Table 7 reports panel GLS regressions of firm performance

\begin{tabular}{|c|c|c|c|c|c|c|}
\hline \multirow{2}{*}{$\begin{array}{l}\text { Dependent } \\
\text { Variable } \\
\text { Independent } \\
\text { Variable }\end{array}$} & \multicolumn{2}{|c|}{ ROA } & \multicolumn{2}{|c|}{ ROE } & \multicolumn{2}{|c|}{ TOBINS_Q } \\
\hline & Coefficient & Prob. & Coefficient & Prob. & Coefficient & Prob. \\
\hline C & -29.843 & 0.0000 & -122.33 & 0.0000 & 5.661 & 0.0107 \\
\hline ESR_SCORE_ & -0.198 & $0.0030 * * *$ & 0.283 & $0.0011 * * *$ & 0.008 & 0.4324 \\
\hline CAP_EX_TA_ & 0.085 & 0.6515 & 1.253 & 0.5612 & -0.119 & 0.4214 \\
\hline CASH_TA_- & 13.35 & $0.0000 * * *$ & -7.856 & 0.1675 & -1.465 & 0.1101 \\
\hline CUR_RAT & 0.285 & $0.0005 * * *$ & 0.502 & $0.0116^{* *}$ & -0.023 & $0.0364 * *$ \\
\hline FIX_ĀAS_RĀT & -9.898 & $0.0000 * * *$ & 18.50 & $0.0000 * * *$ & 0.477 & 0.2451 \\
\hline LN_FIR_AGE_- & -0.299 & 0.2282 & 2.756 & $0.0046^{* * *}$ & -0.169 & 0.5337 \\
\hline LN_TA_ & 2.581 & $0.0000 * * *$ & 8.895 & $0.0000 * * *$ & -0.383 & $0.0079 * * *$ \\
\hline $\mathbf{M B V}_{-}$ & 0.289 & $0.0000 * * *$ & -2.516 & $0.0000 * * *$ & 0.020 & 0.4053 \\
\hline $\begin{array}{l}\text { Adjusted } \\
\text { squared }\end{array}$ & 0.891 & & 0.836 & & 0.047 & \\
\hline F-statistic & 52.23 & & 32.84 & & 3.862 & \\
\hline $\begin{array}{l}\text { Prob(F- } \\
\text { statistic) }\end{array}$ & 0.000 & & 0.000 & & 0.002 & \\
\hline
\end{tabular}

These table reports panel GLS regressions of firm performance. The dependent variable is firm performance, which is measured by ROA, ROE and Tobin's Q. *, **, and *** represent statistical significance at the $10 \%$, $5 \%$, and $1 \%$ levels, respectively.

Vol.2, No.1, Part 1., Jan. 2021 
The results show in Model (1A), a negative significant effect between the ESR score of a coefficient of (-0.198) and Significant level. of (0.003) and ROA. And this is due to the high cost of operation expensed on the environmental social activities in the organization leading into a negative effect of the profitability of the company. And this is consistent with (Friedman, 1970) who argues that the premise of the negative effect of social responsibility on financial performance is that the expected cost of social responsibility is likely to outweigh the resulting benefits.

Model (1B) results show a positive significant effect between ESR score and ROE with a coefficient of (0.283) and a Significant level. of (0.0011). And this result is consistent with (Derwall, et al., 2005) studies of firm performance with the relationship with the corporate environmental performance for the period of 1995 to 2003 and found that companies with higher corporate environmental performance delivered higher returns. We found that environmental social responsibilities have a positive implication for the firm value. Strong reputation in environmental and social responsibility disclosure helps firm attract quality employee due to (e.g. fair trade, equality of pay etc.) which would enhance employee morale and productivity, building goodwill and trust with stakeholders and reduce transaction cost (e.g. lower employee turnover). And this reflects in the market value of the firm in a positive and significant way. On the other hand, in Model (1C) the results show an insignificant effect between the ESR score and Tobin's Q.

ह91

Vol.2, No.1, Part 1., Jan. 2021 
Scientific Journal for Financial and Commercial Studies and Researches

Dr. Mohamed EL-Hindawy; Dr. Amir Shousha \& Ahmed Rady

Table 8 reports the summary of hypotheses 3 result.

\begin{tabular}{llll}
\hline Hypothesis results & ROA & ROE & TOBINS_Q \\
\hline $\begin{array}{l}\text { Hypothesis 3 Environmental social } \\
\text { responsibility has a significant effect on firm } \\
\text { performance. }\end{array}$ & Accept & Accept & reject \\
& & & \\
& & & \\
\hline
\end{tabular}

\subsubsection{The mediating role of ESR.}

In this section, we display the results regarding the mediating effects of ESR score, on the relationship between corporate governance and financial performance. According to Baron \& Kenny (1986), to test the mediating effect (Hypothesis 4), which predicts that ESR play the mediation role of $\mathrm{CG}$ on FP, it is important to look at the regression results of Eq. (1) through Eq. (4).

Table 9 reports panel GLS regressions of the mediating effect between CG and FP.

ב ह99

Vol.2, No.1, Part 1., Jan. 2021 
Table 9: panel GLS regressions of the mediating effect between CG and FP.

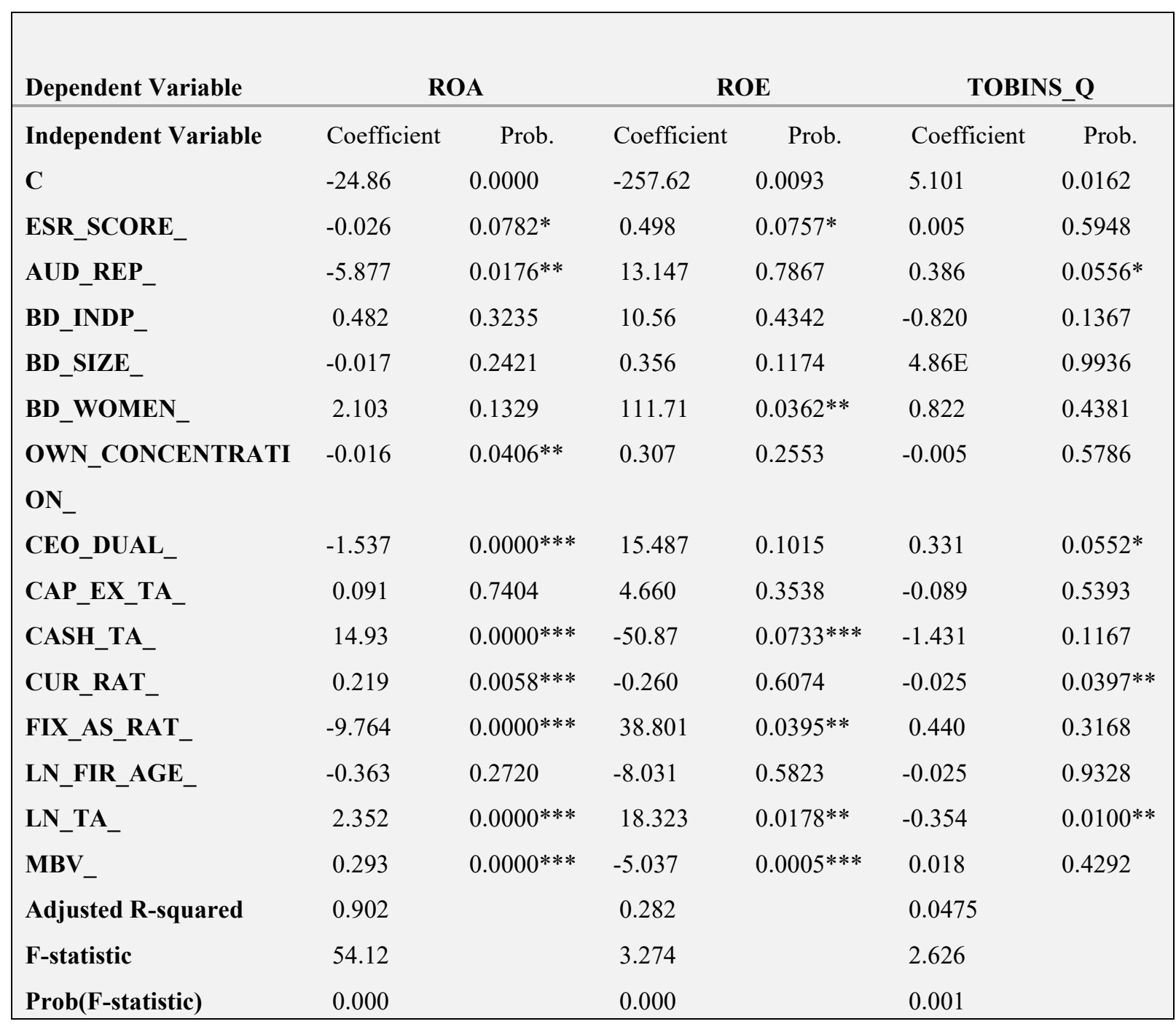

This Table reports panel GLS regressions of the mediating effect between CG and FP. ${ }^{*}, * *$, and $* * *$ represent statistical significance at the $10 \%, 5 \%$, and $1 \%$ levels, respectively.

Vol.2, No.1, Part 1., Jan. 2021 
To test for the presence of the mediating effect, the following conditions must hold: First, the independent variable CG must affect the dependent variable FP in Eq. (1). Second, the independent variable CG must have the effect on the mediator ESR in Eq. (2). Third, the mediator ESR must affect the dependent variable FP in Eq. (3). Fourth, if the above three conditions are all hold and the effect of independent variable CG on dependent variable FP in Eq. (4) is weaker than that of Eq. (1), there is an evidence for a partial mediator, and if the effect of independent variable CG on dependent variable FP in Eq.(4) become insignificant, there is an evidence of a full mediation.

The results show under model (4A) that the value of the coefficient of the audit reputation in EQ (1a) is (6.712) and the value of audit reputation, in EQ (4a) is (5.877) which become weaker thought according to Baron \& Kenny (1986). The results show that ESR score partially mediate the relationship between audit reputation and ROA. Also, the results show that the value of the coefficient for the ownership concentration in EQ (1a) is (0.020) and in EQ (4a) is (0.016) thought the results shows that ESR score partially mediate the relationship between Ownership concentrations and ROA. Finally, the results show that the value of the coefficient for the role duality in EQ (1a) is (1.567) and in EQ (4a) is (1.537), thought the results shows that ESR score partially mediate the relationship between role duality and ROA.

Testing the result of the mediating effect on model (4B) the results show that the value of role Duality in EQ (1B) is significant at prob. (.00001) and the shows an insignificant result at Significant level. (0.101) in EQ (4B). Though the results suggest that ESR score fully mediate the relationship between role duality and ROE.

Vol.2, No.1, Part 1., Jan. 2021 
Table 10: summary of hypotheses 4 results

\begin{tabular}{llll}
\hline Hypothesis results & ROA & ROE & Tobin's \\
\hline $\begin{array}{l}\text { Hypothesis 4.1: ESR mediates the relationship between board } \\
\text { size and firm performance. }\end{array}$ & reject & reject \\
$\begin{array}{l}\text { Hypothesis 4.2: ESR mediates the relationship between board reject } \\
\text { independence and firm performance. }\end{array}$ & reject & reject \\
$\begin{array}{l}\text { Hypothesis } 4.3 \text { ESR mediates the relationship between female reject } \\
\text { directorship and firm performance. }\end{array}$ & reject & reject \\
$\begin{array}{l}\text { Hypothesis } 4.4 \text { ESR mediates the relationship between role } \\
\text { duality and firm performance. }\end{array}$ & Accept & reject \\
$\begin{array}{l}\text { Hypothesis } 4.5 \text { ESR mediates the relationship between ownership } \\
\text { concentration and firm performance. }\end{array}$ & reject & reject \\
$\begin{array}{l}\text { Hypothesis } 4.6 \text { ESR mediates the relationship between audit } \\
\text { reputation and firm performance }\end{array}$ & reject & reject \\
\hline
\end{tabular}

\section{6- Conclusion and managerial implications.}

\section{6-1 Conclusion}

Corporate governance and social responsibilities highlight samples of the hottest topics, especially in developing economies like Egypt which care nowadays on acting under a proper governance and suitable social responsibility toward the society and stakeholder, to be more effective and efficient in the market.

Vol.2, No.1, Part 1., Jan. 2021 
Four questions have been answered: First, dose corporate governance effect firm performance Second, dose environmental social responsibility effects Firm performance third, does corporate governance effects environmental social responsibility decision. And finally dose environmental social responsibility explain (mediate) the relation between corporate governance and firm performance.

Panel data regression was performed on a sample of 66 non financial firms in Egypt during the period from 2010-2018. The model parameters were estimated using generalized least square regression. Six corporate governance indicators (Ownership concentration, Female directorship, Role Duality, Board independence, Board size and Audit reputation) were chosen in testing the hypothesized relationship between corporate governance practices with firm performance, which was measured by return on asset, return on equity and Tobin's q. Moreover, environmental social responsibility factor is measured using the S\&P/EGX ESG ratings Published index.

The result shows that environmental social responsibility has a significant effect on firm performance ROA and ROE. Also, a significant effect between Audit reputation, Ownership concentration and role Duality and environmental social responsibility however, the result shows that there is a mixed relationship between corporate governance and firm performance.

Finally, the empirical results show that environmental social responsibility score partially mediate the relationship between audit reputation, role duality and ownership concentration and return on asset. Moreover, the results show that environmental social responsibility score

Vol.2, No.1, Part 1., Jan. 2021 
fully mediate the relationship between role duality and return on equity. On the other hand, the results show environmental social responsibility doesn't mediate the relationship between corporate governance and Tobin's to the best of our knowledge; we are the first to show that CG exerts the indirect effect on firm performance via ESR for firms in a developing market economy.

The study, to the best of our knowledge, is the first one to demonstrate the empirical evidence regarding the effect of mediating the environmental and social responsibility on the relationship between corporate governance and firm performance. Furthermore, the paper adds to the literature by providing the following evidence in one of the emerging countries like Egypt.

\section{6-2 Managerial Implications}

The findings of this research demonstrate some important tips for the implication of the environmental and social responsibility of the Egyptian institutions. Since, all managers are directed to enhance their firm performance, and attract more investors. The empirical results of the study, shows that environmental and social responsibility partially explains the relationship between the corporate governance and firm performance, therefore, managers will have a great opportunity to optimize their firms' attractiveness in the eyes of the investors, by justifying their social and environmental program and activities. We found that when a firm engage in ESR activities, this enhance the firm performance, from the profitability perspective (ROA) and also from the investors perspective as it increases the firms ROE as showed in the results before.

Vol.2, No.1, Part 1., Jan. 2021 
And by interpreting the findings of the research we propose that good corporate governance results in positive environmental and social responsibilities, and this finding are consistent with (Khan and Muttakin, 2013) who propose that high levels of corporate governance structure could safeguard stakeholder's right and ensure social responsibility. Good corporate governance ensures high level of social responsibility disclosure and thereby attracts more investors and achieves sustainable development. Therefore, we conclude that the possession of good corporate governance is the basis to undertaking social responsibilities in the organization.

\section{7- Limitations and Recommendation for Future Research}

This study was limited to most active 100 companies in the Egyptian Exchange, which constitute the EGX100 index from 2010 to 2018. Among the samples, there are 66 companies that can be used as other samples cannot provide full set of information which is needed in this study. This would cause the samples not to properly represent the whole population. Also, the research excluded the financial institutions from the sample, which represents an important sector in the whole population. Moreover, there are few companies that have changed the time period of their annual reports due to their companies' internal decisions. This could affect the accuracy of data as well. Finally, there are only six internal indicators used for (corporate governance practices) and three indicators used in (firm performance). Different results will be obtained by using different indicators.

0.0

Vol.2, No.1, Part 1., Jan. 2021 
This study can be improved by analyzing a longer time period. It is recommended that the financial data ranging over 20 years would be reliable. It cannot be denied that the longer time period of research can provide more accurate results. There are possible numbers of variables that can be used to investigate the determinants of corporate governance practices and firm performance. This study only used internal mechanisms as the tools to indicate the corporate governance practices of companies. Future researchers can use external mechanisms as well. On the contrary, firms' ROA, ROE and Tobin's Q was used to indicate the firm performance. There are still many other indicators such as earning per share (EPS). Finally, other researches could include financial institutions, in their research sample, which will give more indication of the governance researches in the future.

\section{8- Acknowledgements}

This paper is abridged version of the first author's doctoral dissertation at Damietta University. The first author is grateful to his dissertation committee, prof. Mohamed A.M. EL-Hindawy and DR. Amir A. Shusha for their guidance and suggestions. Also, the first author is grateful to DR Yousef Prince for his help and support in the paper.

0.9

Vol.2, No.1, Part 1., Jan. 2021 


\section{Reference}

- Abdullah, S. N., \& Nasir, N. M. (2004). Accrual management and the independence of the boards of directors and audit committees. International Journal of Economics, Management and Accounting, 12(1).

http://journals.iium.edu.my/enmjournal/index.php/enmj/article/view/ 97.

- Adams, C., \& Zutshi, A. (2004). Corporate social responsibility: why business should act responsibly and be accountable. Australian accounting review, 14(34), 31-39.

- Adams, R. B., \& Mehran, H. (2003). Is corporate governance different for bank holding companies?. Available at SSRN 387561

- Adams, R.B. and Ferreira, D. (2009), "Women in the boardroom and their impact on governance and performance", Journal of Financial Economics, Vol. 94 No. 2, pp. 291-309. http://hermes-ir.lib.hitu.ac.jp/rs/bitstream/10086/29282/1/WP2008-7.pdf

- Ahmed Haji, A. (2013), "Corporate social responsibility disclosures over time: evidence from Malaysia", Managerial Auditing Journal, $\begin{array}{lllll}\text { Vol. } & 28 & \text { No. } & 7, & \text { pp. }\end{array}$ https://scholar.google.com/scholar?hl=en\&as_sdt=0\%2C5\&q=\%E2 $\% 80 \%$ A2\%09Ahmed + Haji $\% 2 \mathrm{C}+\mathrm{A} .+\% 282013 \% 29 \% 2 \mathrm{C}+\% \mathrm{E} 2 \% 80$ $\% 9$ CCorporate + social + responsibility + disclosures + over + time $\% 3 \mathrm{~A}+\mathrm{e}$ vidence + from + Malaysia $\% \mathrm{E} 2 \% 80 \% 9 \mathrm{D} \% 2 \mathrm{C}+$ Managerial + Auditing+ Journal $\% 2 \mathrm{C}+$ Vol. $+28+$ No. $+7 \% 2 \mathrm{C}+$ pp. $+647-676 . \& b \operatorname{tnG}=$

- Ali, W., Frynas, J.G. and Mahmood, Z. (2017), Determinants of Corporate Social Responsibility (CSR) disclosure in Developed and Developing Countries: A Literature Review, Corporate Social Responsibility and Environmental Management. http://eclass.teiion.gr/modules/document/file.php/DE DE305/Ali Frynas Mahmood 2017.pdf

- Anderson, R. C., Mansi, S. A., \& Reeb, D. M. (2004). Board characteristics, accounting report integrity, and the cost of 
debt. Journal of accounting and economics, 37(3), 315-342. https://www.davidreeb.net/uploads/4/8/0/7/48079951/jae boards_an d agency debt.pdf

- Aupperle, K. E., Carroll, A. B., \& Hatfield, J. D. (1985). An empirical examination of the relationship between corporate social responsibility and profitability. Academy of management Journal, 28(2), 446-463. https://www.researchgate.net/profile/Archie_Carroll/publication/325 001131_An_Empirical_Examination_of the Relationship_between Corporate Social Responsibility and Profitability/links/5af7282e 0f 7e9b026bd49b9a/An-Empirical-Examination-of-the-Relationshipbetween-Corporate-Social-Responsibility-and-Profitability.pdf

- Barakat, F.S., Pérez, M.V.L. and Ariza, L.R. (2015), “Corporate social responsibility disclosure (CSRD) determinants of listed companies in palestine (PXE) and Jordan (ASE)", Review of Managerial Science, $\begin{array}{lllll}\text { Vol. } & 9 & \text { No. } & 4, & \text { pp. }\end{array}$ https://scholar.google.com/scholar?hl=en\&as_sdt=0\%2C5\&q=\%E2 $\% 80 \%$ A2\%09Barakat $\% 2$ C + F.S. $\% 2 \mathrm{C}+\mathrm{P} \% \mathrm{C} 3 \% \mathrm{~A} 9 \mathrm{rez} \% 2 \mathrm{C}+\mathrm{M}$. V.L.+ and + Ariza $\% 2$ C + L.R. $+\% 282015 \% 29 \% 2 \mathrm{C}+\% \mathrm{E} 2 \% 80 \% 9 \mathrm{CC}$ orporate + social + responsibility + disclosure $+\% 28 \mathrm{CSRD} \% 29+$ determinants + of + listed + companies + in + palestine $+\% 28 \mathrm{PXE} \% 29+$ and + Jordan $+\% 28 \mathrm{AS}$ E $\% 29 \% \mathrm{E} 2 \% 80 \% 9 \mathrm{D} \% 2 \mathrm{C}+$ Review + of + Managerial + Science $\% 2 \mathrm{C}+\mathrm{V}$ ol. $+9+$ No. $+4 \% 2 \mathrm{C}+$ pp. $+681-702 . \& b \operatorname{tnG}=$

- Baron, R. M., \& Kenny, D. A. (1986). The moderator-mediator variable distinction in social psychological research: Conceptual, strategic, and statistical considerations. Journal of personality and social psychology, 51(6), 1173. http://webcom.upmfgrenoble.fr/LIP/Perso/DMuller/GSERM/Articles /Journal $\% 20$ of $\% 20$ Personality $\% 20$ and $\% 20$ Social $\% 20$ Psychology $\% 2$ 01986\%20Baron.pdf

- Beltratti, A. (2005). The complementarity between corporate governance and corporate social responsibility. The Geneva Papers on 
Risk and Insurance-Issues and Practice, 30(3), 373-386. https://link.springer.com/article/10.1057/palgrave.gpp.2510035

- Bhabra, G. S. (2007). Insider ownership and firm value in New Zealand. Journal of Multinational Financial Management, 17(2), 142154.

https://www.sciencedirect.com/science/article/pii/S1042444X06000 $\underline{508}$

- Bhagat, S., \& Bolton, B. (2008). Corporate governance and firm performance. Journal of corporate finance, 14(3), 257-273. https://pdfs.semanticscholar.org/2369/873de26bfc2fcee4c4264cb842 db877688b7.pdf

- Byrd, J., Cooperman, E. S., \& Wolfe, G. A. (2009). Another look at director independence. Int Rev Account Bank Financ,1, 116. https://www.researchgate.net/profile/John_Byrd2/publication/22842 3600_Another_Look_at_Director_Independence/links/0deec51818ef 5b66fa000000.pdf? inViewer=true\&pdfJsDownload=true \&disableCo verPage $=$ true \&origin $=$ publication_detail.

- Cadbury, A., 2000. The corporate governance agenda: J. Corp. Govern. 8, 7---15 (Practice-Based Papers).

- Casillas, J. C., \& Moreno, A. M. (2010). The relationship between entrepreneurial orientation and growth: The moderating role of family involvement. Entrepreneurship \& Regional Development, 22(3-4), 265-291.

https://www.tandfonline.com/doi/abs/10.1080/08985621003726135

- Chan, M. C., Watson, J., \& Woodliff, D. (2014). Corporate governance quality and CSR disclosures. Journal of Business Ethics, 125(1), 59-73.

- Chang, Y.K., Oh, W.Y., Park, J.H. and Jang, M.G. (2017), “Exploring the relationship between board characteristics and CSR: empirical evidence from Korea", Journal of Business Ethics, Vol. 140 No. 2, pp. 225-242. https://link.springer.com/content/pdf/10.1007/s10551-0152651-z.pdf 
- Chen, C. W., Lin, J. B., \& Yi, B. (2008). CEO duality and firm performance: An endogenous issue. Corporate Ownership and Control, 6(1),

https://www.researchgate.net/profile/Pierre_Erasmus/publication/24 2647474_Value based_financial_performance measures_An_evalu ation_of relative and incremental_information_content/links $/ 55 \mathrm{c} 49$ 3b308aeb97567416db0.pdf\#page $=56$

- Chen, Z., Cheung, Y. L., Stouraitis, A., \& Wong, A. W. (2005). Ownership concentration, firm performance, and dividend policy in Hong Kong. Pacific-Basin Finance Journal, 13(4), 431-449. https://www.sciencedirect.com/science/article/pii/S0927538X05000 $\underline{120}$

- Christmann, P. (2000). 'Effects of "best practices" of environmental management on cost advantage: the role of complementary assets. Academy of Management Journal, 43, 663-80.

- Cochran, P. L., \& Wood, R. A. (1984). Corporate social responsibility and financial performance. Academy of management Journal, 27(1), 42-56. https://journals.aom.org/doi/abs/10.5465/255956

- Danoshana, S., \& Ravivathani, T. (2019). The impact of the corporate governance on firm performance: A study on financial institutions in Sri Lanka. SAARJ Journal on Banking \& Insurance Research, 8(1), 62-67.

- Davis, J. H., Schoorman, F. D., \& Donaldson, L. (1997). Toward a stewardship theory of management. Academy of Management review, 22(1), 20-47. https://pdfs.semanticscholar.org/bdf0/5b25b5584c760798bc0a9605e db1bce31dac.pdf

- DeFond, M. L., \& Lennox, C. S. (2011). The effect of SOX on small auditor exits and audit quality. Journal of Accounting and Economics, 52(1), 21-40. https://msbfile03.usc.edu/digitalmeasures/clennox/intellcont/JAE11$\underline{1 . p d f}$ 
- Dehaene, A., De Vuyst, V., \& Ooghe, H. (2001). Corporate performance and board structure in Belgian companies. Long range planning, 34(3),

383-398.

https:/www.sciencedirect.com/science/article/abs/pii/S00246301010 $\underline{00450}$

- Derwall, J., N. Guenster, R. Bauer, \& K.C.G. Koedijk (2005).The ecoefficiency premium puzzle, Financial Analysts Journal 61, 51-63. https://www.tandfonline.com/doi/abs/10.2469/faj.v61.n2.2716

- Detthamrong, U., Chancharat, N., \& Vithessonthi, C. (2017). Corporate governance, capital structure and firm performance: evidence from Thailand. Research in International Business and Finance, 42, 689-709. https://www.sciencedirect.com/science/article/abs/pii/S02755319163 $\underline{03324}$

- Dhaliwal, D. S., Radhakrishnan, S., Tsang, A., \& Yang, Y. G. (2012). Nonfinancial disclosure and analyst forecast accuracy: International evidence on corporate social responsibility disclosure. The Accounting Review, 87(3), 723-759. https://www.aaajournals.org/doi/abs/10.2308/accr-10218

- Donaldson, L., \& Davis, J. H. (1991). Stewardship theory or agency theory: CEO governance and shareholder returns. Australian Journal of management, 16(1), 49-64. https://journals.sagepub.com/doi/pdf/10.1177/031289629101600103 ?casa token=F7pjfjCSKHUAAAAA:qmn3qA2wuIQi91HOBIpHFJ CTgygOkciIpiWbJ6_ZgMh1WpkDRvKyCQHKK7eKYUCzhdQqil Cbja4euw

- Donaldson, T., \& Preston, L. E. (1995). The stakeholder theory of the corporation: Concepts, evidence, and implications. Academy of $\begin{array}{llll}\text { management } & \text { Review, 20(1), } & 65 & 91 .\end{array}$ https://mycourses.aalto.fi/pluginfile.php $/ 556705 / \mathrm{mod}$ resource/conte nt/1/READING\%20Stakeholder\%20Theory.pdf 
- Duffhues, P., \& Kabir, R. (2008). Is the pay-performance relationship always positive? Evidence from the Netherlands. Journal of multinational financial management, 18(1), 45-60. https://ris.utwente.nl/ws/portalfiles/portal/17089966/Duffhues07is.pd $\underline{f}$

- Echave, J. O., \& Bhati, S. S. (2010). Determinants of social and environmental disclosures by Spanish companies. https://ro.uow.edu.au/cgi/viewcontent.cgi?article $=2955 \&$ context $=$ co mmpapers

- Egyptian Exchange website, http://www.egx.com.eg/english/homepage.aspx,

- Eisenberg, T., Sundgren, S., \& Wells, M. T. (1998). Larger board size and decreasing firm value in small firms. Journal of financial economics, 48(1), https://scholarship.law.cornell.edu/cgi/viewcontent.cgi? article $=1403$ $\underline{\text { \&context }=\text { facpub }}$

- Epps, R. W., Cereola, S. J., 2008. Do institutional shareholder service (ISS) corporate governance rating reflect a company's operating performance? Critical Perspective on Accounting. 1135-1148. https://www.sciencedirect.com/science/article/pii/S10452354070008 $\underline{58}$

- Erhardt, N. L., Werbel, J. D., \& Shrader, C. B. (2003). Board of director diversity and firm financial performance. Corporate governance: An international review, 11(2), 102-111. https://lib.dr.iastate.edu/cgi/viewcontent.cgi?article $=1005 \&$ context $=$ management pubs

- Fama, E. F. (1980). Agency problems and the theory of the firm. Journal of political economy, 88(2), 288-307 https://www.journals.uchicago.edu/doi/abs/10.1086/260866

- Fama, E. F., \& Jensen, M. C. (1983). Separation of ownership and control. The journal of law and Economics, 26(2), 301-325. 
https://pdfs.semanticscholar.org/94a8/f1e59b6424fd96ad7e28588efa 04fccf042b.pdf

- Friedman, M. (1970). A Friedman doctrine: The social responsibility of business is to increase its profits. The New York Times Magazine, 13(1970),

https://cedar.wwu.edu/cgi/viewcontent.cgi? article $=1006 \&$ context $=\mathrm{m}$ gmt facpubs

- García-Meca, E., García-Sánchez, I. M., \& Martínez-Ferrero, J. (2015). Board diversity and its effects on bank performance: An international analysis. Journal of Banking \& Finance, 53, 202-214 https://www.sciencedirect.com/science/article/abs/pii/S03784266140 $\underline{03811}$

- Ghazali, N. A. M. (2007). Ownership structure and corporate social responsibility disclosure: Some Malaysian evidence. Corporate Governance, 7(3), 251-266.

- Giannarakis, G. (2014), "Corporate governance and financial characteristic effects on the extent of corporate social responsibility disclosure", Social Responsibility Journal, Vol. 10 No. 4, pp. 569-590. https://www.emerald.com/insight/content/doi/10.1108/SRJ-02-2013$\underline{0008 / \text { full/html }}$

- Gibbins, M., Richardson, A., \& Waterhouse, J. (1990). The management of corporate financial disclosures: Opportunism, ritualism, politics and processes. Journal of Accounting Research, 28(1), 121-143. https://www.jstor.org/stable/2491219?seq=1

- Gray, R., Kouhy, R., \& Lavers, S. (1995). Corporate social and environmental reporting: A review of the literature and longitudinal study of UK disclosure. Accounting, Auditing \& Accountability Journal,

https://www.emerald.com/insight/content/doi/10.1108/09513579510 $\underline{146996 / \mathrm{full} / \mathrm{html} \text { ?mobileUi }=0 \& \text { full } \mathrm{Sc}=1 \& \mathrm{mbSc}=1 \& \text { full } \mathrm{Sc}=1 \& \text { fullS }}$ $\underline{\mathrm{c}=1 \& \text { fullSc}=1 \text { \#loginreload }}$ 
- Grougiou, V., Dedoulis, E., \& Leventis, S. (2016). Corporate social responsibility reporting and organizational stigma: The case of "sin" industries. Journal of Business Research, 69, 905-914. https://ruomo.lib.uom.gr/bitstream/7000/361/3/CSR\%20Sin\%20Indu $\underline{\text { stries.pdf }}$

- Gujarati, D.(2003). Basic econometrics (4th edition).New York, McGraw-Hill. https://irlibrary.ku.ac.ke/bitstream/handle/123456789/10136/Effects\%20of\% 20Working $\% 20$ Capital $\% 20$ Management $\% 20$ on $\% 20$ Performance.pdf ? sequence $=4$

- Haniffa, R. M., \& Cooke, T. E. (2005). The impact of culture and governance on corporate social reporting. Journal of Accounting and Public Policy, 24(5), 391-430. https://www.sciencedirect.com/science/article/pii/S02784254050003 $\underline{47}$

- Haniffa, R., Hudaib, M., 2006. Corporate governance structure and performance of Malaysian listed companies. J. Bus. Finance Account. 33 , 1034-1062.

https://onlinelibrary.wiley.com/doi/full/10.1111/j.14685957.2006.00594.x

- Harjoto, M. A., \& Jo, H. (2011). Corporate governance and CSR nexus. Journal of business ethics, 100(1), 45-67. https://link.springer.com/article/10.1007/s10551-011-0772-6

- Hausman, J. (1978).Specification tests in econometrics. Econometric a, 46 , 1251-1271. https://dspace.mit.edu/bitstream/handle/1721.1/64309/specificationte s00haus.pdf? sequence $=1$

- Heidrick, S. (2007). 10th Annual Corporate Board Effectiveness Study. https://papers.ssrn.com/sol3/papers.cfm?abstract id=1440750

- Hossain, M., Prevost, A. K., \& Rao, R. P. (2001). Corporate governance in New Zealand: The effect of the 1993 Companies Act on the relation between board composition and firm 
performance. Pacific-Basin Finance Journal, 9(2), 119-145. https://www.sciencedirect.com/science/article/pii/S0927538X01000 $\underline{038}$

http://195.130.87.21:8080/dspace/bitstream/123456789/458/1/Corpo rate $\% 20$ social $\% 20$ responsibility $\% 20$ why $\% 20$ business $\% 20$ should $\% 2$ 0act $\% 20$ responsibly $\% 20$ and $\% 20$ be $\% 20$ accountable.pdf

- http://www.egx.com.eg/english/ListedStocks.aspx, accessed on 25/08/2017.

- http://www.egx.com.eg/english/OverviewEGX100.aspx?Nav=4,acce ssed on $25 / 08 / 2017$.

- http://www.egx.com.eg/English/Services_Reports.aspx, accessed on 25/08/2017.

https://link.springer.com/article/10.1007/s10551-013-1887-8

https://onlinelibrary.wiley.com/doi/abs/10.1111/1467-8683.00175

https://saarj.com/wp-content/uploads/SJBIR-JANUARY-2019FULL-JOURNAL.pdf\#page $=62$

- https://www.decypha.com/en/fundamental-screener, accessed on 25/08/2017.

- https://www.decypha.com/en/index/EGX/EGX100 , accessed on 25/08/2017.

https://www8.gsb.columbia.edu/leadership/sites/leadership/files/Is_C orporate_Governance Different_For_Bank_Holding_Companies.pdf

- Hussain, S., Ahmad, T., \& Hassan, S. (2019). CORPORATE GOVERNANCE AND FIRM PERFORMANCE USING GMM. International Journal of Information, Business and Management, 11(2), 300-316 https://search.proquest.com/openview/67ca460ef63a0207d0a2be455

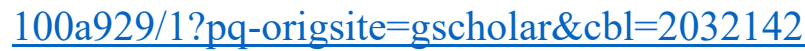

- Ingley, C., Mueller, J., \& Cocks, G. (2011). The financial crisis, investor activists and corporate strategy: will this mean shareholders 
in the boardroom? Journal of Management \& Governance, 15(4), 557587. https://link.springer.com/article/10.1007/s10997-010-9130-9

- Ioannou, I., \& Serafeim, G. (2015). The impact of corporate social responsibility on investment recommendations: Analysts' perceptions and shifting institutional logics.Strategic Management Journal, 36(7), 1053-1081.

https://onlinelibrary.wiley.com/doi/full/10.1002/smj.2268

- Jackling, B., \& Johl, S. (2009). Board structure and firm performance: Evidence from India's top companies. Corporate Governance: An International Review, 17(4), 492-509. https://onlinelibrary.wiley.com/doi/full/10.1111/j.1467$\underline{8683.2009 .00760 . x}$

- Jamali, D., Safieddine, A. M., \& Rabbath, M. (2008). Corporate governance and corporate social responsibility synergies and interrelationships. Corporate Governance: An International Review, 16(5), 443-459.

https://onlinelibrary.wiley.com/doi/full/10.1111/j.14678683.2008.00702.x

- Jensen, M. C., \& Meckling, W. H. (1976). Theory of the firm: Managerial behavior, agency costs and ownership structure. Journal of financial economics, 3(4), 305-360. https://onlinelibrary.wiley.com/doi/full/10.1111/j.14678683.2008.00702.x

- Jensen, M.C. (1993), "The modern industrial revolution, exit, and the failure of internal control systems", The Journal of Finance, Vol. 48 No. 3, pp. 831-880. https://onlinelibrary.wiley.com/doi/full/10.1111/j.14678683.2008.00702.x

- Johnson, R. A., \& Greening, D. W. (1999). The effects of corporate governance and institutional ownership types on corporate social performance. Academy of management journal, 42(5), 564-576. https://journals.aom.org/doi/abs/10.5465/256977 
- Kaplan, S. N., \& Zingales, L. (1997). Do investment-cash flow sensitivities provide useful measures of financing constraints? The Quarterly Journal of Economics, 112, 169-215. http://people.stern.nyu.edu/eofek/PhD/papers/KZ_Do_QJE.pdf

- Karpoff, J. M. (2001). The impact of shareholder activism on target companies: A survey of empirical findings. Available at SSRN 885365. https://papers.ssrn.com/sol3/papers.cfm?abstract id=885365

- Khan, A., Muttakin, M.B., 2013. Corporate governance and corporate social responsibility disclosures: evidence from an emerging economy. J. Bus. Ethics $114 \quad$ (2), $207 \mathrm{e} 223$. https://www.research.manchester.ac.uk/portal/en/publications/corpor ate-governance-and-corporate-social-responsibility-disclosuresevidence-from-an-emerging-economy(453433bd-2bc6-4dd8-9ba6bfc83726767d)/export.html

- Kiel, G. C., \& Nicholson, G. J. (2003). Board composition and corporate performance: How the Australian experience informs contrasting theories of corporate governance. Corporate Governance: An International Review, 11(3), 189-205. https://onlinelibrary.wiley.com/doi/pdf/10.1111/1467-8683.00318

- Konrad, A.M., Kramer, V. and Erkut, S. (2008), "Critical mass: the impact of three or more women on corporate boards", Organizational Dynamics, Vol. 37 No. 2, pp. 145-164. https://www.researchgate.net/profile/Alison_Konrad/publication/256 923992_Critical_Mass_The Impact_of_Three_or_More_Women_o n_Corporate_Boards/links/5873cde008aebf17d3b09d99/CriticalMass-The-Impact-of-Three-or-More-Women-on-CorporateBoards.pdf

- Lakhal, F. (2005), "Voluntary earnings disclosures and corporate governance: evidence from France", Review of Accounting and Finance, Vol. 4 No. 3, pp. 64-85. https://scholar.google.com/scholar?hl=en\&as_sdt=0\%2C5\&q=\%E2 $\% 80 \%$ A2\%09Lakhal $\% 2 \mathrm{C}+\mathrm{F} .+\% 282005 \% 29 \% 2 \mathrm{C}+\% \mathrm{E} 2 \% 80 \% 9 \mathrm{CVO}$ 
luntary+earnings + disclosures + and + corporate + governance $\% 3 \mathrm{~A}+$ evid ence + from + France $\% \mathrm{E} 2 \% 80 \% 9 \mathrm{D} \% 2 \mathrm{C}+$ Review + of + Accounting + and + Finance $\% 2 \mathrm{C}+$ Vol. $+4+$ No. $+3 \% 2 \mathrm{C}+$ pp. $+64-85 . \& b \operatorname{bnG}=$

- Lang, L.H., Stulz, R.M., 1994. Tobin's Q, corporate diversification, and firm performance. J. Political Econ. 102 (6). https://www.nber.org/papers/w4376.pdf

- Letendre, L. (2004), "The dynamics of the boardroom”, Academy of Management Perspectives, Vol. 18 No. 1, pp. 101-104. https://journals.aom.org/doi/abs/10.5465/ame.2004.12689547

- Levrau, A., \& Van den Berghe, L. A. (2007). Corporate governance and Board Effectiveness: beyond formalism. ICFAI Journal of Corporate Governance, 6(4), 58-85. https://repository.vlerick.com/bitstream/handle/20.500.12127/2267/L evrau_A_WP_CorporateGovernanceandBoardEffectiveness.pdf?seq uence $=1$ \&is Allowed $=\mathrm{y}$

- Liao, L., Lin, T. P., \& Zhang, Y. (2018). Corporate board and corporate social responsibility assurance: Evidence from China. Journal of Business Ethics, 150(1), 211-225. https://ink.springer.com/article/10.1007/s10551-016-3176-9

- Majumder, T.H., Akter, A. and Li, X. (2017), "Corporate governance and corporate social disclosures: a Meta-analytical review", International Journal of Accounting and Information Management, $\begin{array}{llllll}\text { Vol. } & 25 & \text { No. } & 4, & \text { pp. } & 434-458 .\end{array}$ https://www.emerald.com/insight/content/doi/10.1108/IJAIM-012017-0005/full/pdf

- Mak, Y. T., \& Kusnadi, Y. (2005). Size really matters: Further evidence on the negative relationship between board size and firm value. Pacific-Basin finance journal, 13(3), 301-318. https://www.sciencedirect.com/science/article/pii/S0927538X04000 $\underline{733}$

- Margolis, J. D., \& Walsh, J. P. (2003). Misery loves companies: Rethinking social initiatives by business. Administrative science 
quarterly, 48(2),

268-305.

https://journals.sagepub.com/doi/pdf/10.2307/3556659?casa token= exVxvR5X4v8AAAAA:rRDYqGiV06h3c7V0iRi176kcAKCMGsd2 hFPSdygrdoTBI5ssnsIP5J3c8DhitBFD6ttLmyTIagZ w

- Maury, B. (2006). Family ownership and firm performance: Empirical evidence from Western European corporations. Journal of corporate finance, 12(2),

321-341. https://www.sciencedirect.com/science/article/pii/S09291199050004 $\underline{04}$

- McDonald, M. L., Khanna, P., \& Westphal, J. D. (2008). Getting them to think outside the circle: Corporate governance, CEOs' external advice networks, and firm performance. Academy of Management Journal, 51(3),

453-475.

http://webuser.bus.umich.edu/westjd/Articles/mcdonald\%20et $\% 20 \mathrm{al}$ \%2008\%20amj.pdf

- McGuire, J. B., Sundgren, A., \& Schneeweis, T. (1988). Corporate social responsibility and firm financial performance. Academy of management Journal, 31(4), 854-872. https://journals.aom.org/doi/abs/10.5465/256342

- McWilliams, A., \& Siegel, D. (2000). Corporate social responsibility and financial performance: correlation or misspecification?. Strategic management journal, 21(5), $603-$ 609.https://onlinelibrary.wiley.com/doi/abs/10.1002/(SICI)10970266(200005)21:5\%3C603::AID-SMJ101\%3E3.0.CO;2-3

- Mishra, C. S., Randøy, T., \& Jenssen, J. I. (2001). The effect of founding family influence on firm value and corporate governance. Journal of International Financial Management \& Accounting, 12(3), 235-259. https://onlinelibrary.wiley.com/doi/abs/10.1111/1467-646X.00073

- Muniandy, B., \& Hillier, J. (2015). Board independence, investment opportunity set and performance of South African firms. PacificBasin Finance Journal, 35, 108-124. 
https://www.sciencedirect.com/science/article/pii/S0927538X14000 $\underline{912}$

- Muth, M., \& Donaldson, L. (1998). Stewardship theory and board structure: A contingency approach. Corporate Governance: An International Review, 6(1), 5-28. https://onlinelibrary.wiley.com/doi/abs/10.1111/1467-8683.00076

- Muttakin, M.B., Khan, A. and Subramaniam, N. (2015), "Firm characteristics, board diversity and corporate social responsibility: evidence from Bangladesh", Pacific Accounting Review. 27 No. 3, pp.

https://www.emerald.com/insight/content/doi/10.1108/PAR-012013-0007/full/html

- Neu, D., Warsame, H., \& Pedwell, K. (1998). Managing public impressions: environmental disclosures in annual reports. Accounting, organizations and society, 23(3), 265-282. https://www.sciencedirect.com/science/article/abs/pii/S03613682970 00081

- Nguyen, P. (2011). Corporate governance and risk-taking: Evidence from Japanese firms. Pacific-Basin Finance Journal, 19(3), 278-297. https://www.sciencedirect.com/science/article/pii/S0927538X10000 79X

- Oh, W. Y., Chang, Y. K., \& Martynov, A. (2011). The effect of ownership structure on corporate social responsibility: Empirical evidence from Korea. Journal of Business Ethics, 104(2), 283-297.

- Orazalin, N. (2019). Corporate governance and corporate social responsibility (CSR) disclosure in an emerging economy: evidence from commercial banks of Kazakhstan. Corporate Governance: The International Journal of Business in Society. https://www.emerald.com/insight/content/doi/10.1108/CG-09-2018$\underline{0290 / \text { full/html }}$

- Orlitzky, M., Schmidt, F. L., \& Rynes, S. L. (2003). Corporate social and financial performance: A meta-analysis. Organization 
studies, 24(3),

403-441.

https://www.sciencedirect.com/science/article/abs/pii/S03613682970 00081

- Ortas, E., Moneva, J. M., \& Salvador, M. (2014). Do social and environmental screens influence ethical portfolio performance? Evidence from Europe. BRQ Business Research Quarterly, 17(1), 1121.

https://www.sciencedirect.com/science/article/pii/S11385758120008 $\underline{37}$

- Panasian, C., Prevost, A. K., \& Bhabra, H. S. (2003). Board composition and firm performance: The case of the Dey report and publicly listed Canadian firms. working paper, Department of Finance, Montreal University, Montreal, 26 July. https://www.researchgate.net/profile/Christine Panasian/publication/ 267369693 Board_Composition_and_Firm_Performance The Case of the Dey_Report_and_Publicly_Listed_Canadian_Firms/links/5 593efdc08ae5af2b0ecd4aa/Board-Composition-and-FirmPerformance-The-Case-of-the-Dey-Report-and-Publicly-ListedCanadian-Firms.pdf.

- Pava, M. L., \& Krausz, J. (1996). The association between corporate social-responsibility and financial performance: The paradox of social cost. Journal of business Ethics, 15(3),321-357. https://link.springer.com/content/pdf/10.1007/BF00382958.pdf

- Perks, K. J., Farache, F., Shukla, P., \& Berry, A. (2013). Communicating responsibility-practicing irresponsibility in CSR advertisements. Journal of Business Research, 66(10), 1881-1888. https://www.sciencedirect.com/science/article/abs/pii/S01482963130 $\underline{00337}$

- Pillai, R., \& Al-Malkawi, H. A. N. (2018). On the relationship between corporate governance and firm performance: Evidence from GCC countries. Research in International Business and Finance, 44, 394-410. 
https://www.sciencedirect.com/science/article/abs/pii/S02755319173 $\underline{00958}$

- Post, C., Rahman, N. and Rubow, E. (2011), "Green governance: boards of directors' composition and environmental corporate social responsibility", Business and Society, Vol. 50 No. 1, pp. 189-223. https://journals.sagepub.com/doi/pdf/10.1177/0007650310394642?c asa token $=\mathrm{UPv} 0 \mathrm{O}-$

hFTmIAAAAA:pqik8k0PR5mVPqZcb1zbyf7mdFwdz3WpHFB4chSY9oNzZGzud6bgJI-VNFEEXVuNN3J_vXC4pdSzQ

- Prabowo, M., \& Simpson, J. (2011). Independent directors and firm performance in family controlled firms: evidence from Indonesia. Asian-Pacific Economic Literature, 25(1), 121-132. https:/pdfs.semanticscholar.org/6ae8/67a9558892e586bbc10603344 78a1930bd88.pdf

- Razak, S.E.A. and Mustapha, M. (2013), "Corporate social responsibility disclosures and board structure: evidence from Malaysia", Sains Humanika, Vol. 64 No. 3. file://C:/Users/aa/Downloads/71-141-1-SM\%20(1).pdf

- Rose, C. (2007). Does female board representation influence firm performance? The Danish evidence. Corporate Governance: An International Review, 15(2), 404-413 https://onlinelibrary.wiley.com/doi/full/10.1111/j.1467$\underline{\text { 8683.2007.00570.x }}$

- Sadou, A., Alom, F. and Laluddin, H. (2017), "Corporate social responsibility disclosures in Malaysia: evidence from large companies", Social Responsibility Journal, Vol. 13 No. 1, pp. 177202.

https://scholar.google.com/scholar?hl=en\&as sdt=0\%2C5\&q=Sadou $\% 2 \mathrm{C}+\mathrm{A} . \% 2 \mathrm{C}+\mathrm{Alom} \% 2 \mathrm{C}+\mathrm{F} .+$ and + Laluddin $\% 2 \mathrm{C}+\mathrm{H} .+\% 282017 \% 29$ $\% 2 \mathrm{C}+\% \mathrm{E} 2 \% 80 \% 9 \mathrm{CC}$ orporate + social + responsibility + disclosures + in + Malaysia $\% 3 \mathrm{~A}+$ evidence + from + large + companies $\%$ E2\%80\%9D $\% 2$ 
$\underline{\mathrm{C}+\text { Social }+ \text { Responsibility }+ \text { Journal } \% 2 \mathrm{C}+\text { Vol. }+13+\text { No. }+1 \% 2 \mathrm{C}+\text { pp. }+1}$ 77-202.\&btnG=

- Shaker, M.A. and Elgiziry, K., 2014. Comparisons of asset pricing models in the Egyptian stock market. Accounting and Finance Research, 3(4), pp.24-30.

https://scholar.cu.edu.eg/?q=mah/publications/comparisons-assetpricing-models-egyptian-stock-market

- Shukeri, S. N., Shin, O. W., \& Shaari, M. S. (2012). Does board of director's characteristics affect firm performance? Evidence from Malaysian public listed companies. International Business Research, 5(9),

https://www.academia.edu/download/61092819/Reference 1201911 01-23848-16j0bnh.pdf

- Siddiqui, J. (2010). Development of corporate governance regulations: The case of an emerging economy. Journal of Business Ethics, 91(2), 253-274.

- Singh, M., \& Davidson III, W. N. (2003). Agency costs, ownership structure and corporate governance mechanisms. Journal of Banking \& Finance, 27(5),

793-816.

https://www.sciencedirect.com/science/article/abs/pii/S03784266010 $\underline{02606}$

- Smith, K. (2002). ISO considers corporate social responsibility standards. The Journal for Quality and Participation, 25(3), 42. https://search.proquest.com/openview/c87cd0d0437ecc449b879b2af 7b71fb1/1?pq-origsite $=$ gscholar $\& \mathrm{cbl}=37083$

- Smith, N. C. (2003). Corporate social responsibility: whether or how?. California management review, 45(4), 52-76. https://journals.sagepub.com/doi/pdf/10.2307/41166188?casa token =u3cKLpeISGYAAAAA:ocgP3pTsaidIXPYkrHx7GLvgqWGTbR4 T0vO8ULziljtKK2gp3OqNRLaoUmf8AITuu3Qq-xFKpJDQg

- Stanwick, P. A., \& Stanwick, S. D. (1998). The relationship between corporate social performance, and organizational size, financial 
performance, and environmental performance: An empirical examination. Journal of business ethics, 17(2), 195-204. https://ink.springer.com/content/pdf/10.1023/A:1005784421547.pdf

- Taha, R., \& Elgiziry, K. (2016). A Five-Factor Asset Pricing Model: Empirical Evidence from Egypt. International Journal of Business, 21(4),

http://www.academia.edu/download/59284015/A_FiveFactor_Asset Pricing_Model_Empirical_Evidence_from_EgyptInternational_Journal_of Business20190517-48977-14elh6r.pdf.

- Ullah, M. S., Muttakin, M. B., \& Khan, A. (2019). Corporate governance and corporate social responsibility disclosures in insurance companies. International Journal of Accounting \& Information Management. https://www.emerald.com/insight/content/doi/10.1108/IJAIM-102017-0120/full/html

- Van der Laan Smith, J., Adhikari, A. and Tondkar, R.H. (2005), "Exploring differences in social disclosures internationally: a stakeholder perspective", Journal of Accounting and Public Policy, $\begin{array}{lllll}\text { Vol. } & 24 & \text { No. } & 2, & \text { pp. 123-151. }\end{array}$ https://scholar.google.com/scholar?hl=en\&as sdt $=0 \% 2 \mathrm{C} 5 \& \mathrm{q}=\% \mathrm{E} 2$ $\% 80 \% \mathrm{~A} 2 \% 09 \mathrm{Van}+\mathrm{der}+\mathrm{Laan}+\mathrm{Smith} \% 2 \mathrm{C}+\mathrm{J} . \% 2 \mathrm{C}+\mathrm{Adhikari} \% 2 \mathrm{C}+\mathrm{A}$. + and + Tondkar $\% 2 \mathrm{C}+$ R.H. $+\% 282005 \% 29 \% 2 \mathrm{C}+\% \mathrm{E} 2 \% 80 \% 9 \mathrm{CExplor}$ ing-differences + in + social + disclosures + internationally $\% 3 \mathrm{~A}+\mathrm{a}+$ stake holder+perspective $\% \mathrm{E} 2 \% 80 \% 9 \mathrm{D} \% 2 \mathrm{C}+$ Journal + of + Accounting + and + Public + Policy $\% 2 \mathrm{C}+$ Vol. $+24+$ No. $+2 \% 2 \mathrm{C}+$ pp. $.+123-151 . \& b t n G=$

- Waddock, S. A., \& Graves, S. B. (1997). The corporate social performance-financial performance link. Strategic management journal, 18(4),

303-319.

http://citeseerx.ist.psu.edu/viewdoc/download?doi=10.1.1.912.5298 $\underline{\text { \&rep }=\text { rep } 1 \& \text { type }=p d f}$

- Williams, S. M. (1999). Voluntary environmental and social accounting disclosure practices in the Asia-Pacific region: An 
international empirical test of political economy theory. The International Journal of Accounting, 34(2), 209-238. https://researchrepository.murdoch.edu.au/id/eprint/407/1/01Front.p $\underline{\mathrm{df}}$

- Windsor, D. and Preston, L.E. (1988), "Corporate governance, social policy, and social performance in the multinational corporation", Research in Corporate Social Performance and Policy, Vol. 10, pp. 45-58.

- Wiwattanakantang, Y. (2001). Controlling shareholders and corporate value: Evidence from Thailand. Pacific-Basin Finance Journal, 9(4), 323-362.

http://hermes-ir.lib.hitu.ac.jp/rs/bitstream/10086/13945/1/wp2001-4a.pdf

- Yang, T., \& Zhao, S. (2014). CEO duality and firm performance: Evidence from an exogenous shock to the competitive environment. Journal of Banking \& Finance, 49, 534-552. https:/www.sciencedirect.com/science/article/abs/pii/S03784266140 $\underline{01344}$

- Yermack, D. (1996). Higher market valuation of companies with a small board of directors. Journal of financial economics, 40(2), 185211.

https://iri.hse.ru/data/920/479/1225/Sept $\% 2021 \% 20 \% 235 \% 20$ Cited \%20CG $\% 20$ Higher $\% 20$ market $\% 20$ valuat..with $\% 20 \mathrm{a} \% 20$ small $\% 20 \mathrm{~b}$ oard $\% 20$ of $\% 20$ directors.pdf.

- Zaid, M. A., Wang, M., \& Abuhijleh, S. T. (2019). The effect of corporate governance practices on corporate social responsibility disclosure. Journal of Global Responsibility. https://scholar.google.com/scholar?hl=en\&as_sdt $=0 \% 2 \mathrm{C} 5 \& \mathrm{q}=\mathrm{The}+$ effect + of + corporate + governance + practices + on + corporate + social + re sponsibility + disclosure + Evidence + from + Palestine \&btnG $=$

- Zhang, Q., Chen, L., \& Feng, T. (2014). Mediation or Moderation? The Role of R\&D Investment in the Relationship between Corporate Governance and Firm Performance: Empirical Evidence from the 
Scientific Journal for Financial and Commercial Studies and Researches Dr. Mohamed EL-Hindawy; Dr. Amir Shousha \& Ahmed Rady

Chinese IT Industry. Corporate Governance: An International Review, 22(6)

https://onlinelibrary.wiley.com/doi/full/10.1111/corg.12073

Vol.2, No.1, Part 1., Jan. 2021 